\title{
Myeloid-Derived Suppressor Cells and Pulmonary Hypertension
}

\author{
Andrew J. Bryant ${ }^{1, *(\mathbb{D})}$, Borna Mehrad ${ }^{1}$ (D) , Todd M. Brusko $^{2}$ (D) , James D. West $^{3}$ and \\ Lyle L. Moldawer ${ }^{4}$ \\ 1 Division of Pulmonary and Critical Care Medicine, Department of Medicine, University of Florida College \\ of Medicine, Gainesville, FL 32610, USA; borna.mehrad@medicine.ufl.edu \\ 2 Department of Pathology, Immunology and Laboratory Medicine, University of Florida College of Medicine, \\ Gainesville, FL 32610, USA; tbrusko@ufl.edu \\ 3 Department of Medicine, Vanderbilt University School of Medicine, Nashville, TN 37232, USA; \\ j.west@vanderbilt.edu \\ 4 Department of Surgery, University of Florida College of Medicine, Gainesville, FL 32610, USA; \\ lyle.moldawer@surgery.ufl.edu \\ * Correspondence: andrew.bryant@medicine.ufl.edu; Tel.: +1-352-273-8737
}

Received: 16 July 2018; Accepted: 1 August 2018; Published: 3 August 2018

\begin{abstract}
Myeloid-derived suppressor cells (MDSCs) comprised a heterogeneous subset of bone marrow-derived myeloid cells, best studied in cancer research, that are increasingly implicated in the pathogenesis of pulmonary vascular remodeling and the development of pulmonary hypertension. Stem cell transplantation represents one extreme interventional strategy for ablating the myeloid compartment but poses a number of translational challenges. There remains an outstanding need for additional therapeutic targets to impact MDSC function, including the potential to alter interactions with innate and adaptive immune subsets, or alternatively, alter trafficking receptors, metabolic pathways, and transcription factor signaling with readily available and safe drugs. In this review, we summarize the current literature on the role of myeloid cells in the development of pulmonary hypertension, first in pulmonary circulation changes associated with myelodysplastic syndromes, and then by examining intrinsic myeloid cell changes that contribute to disease progression in pulmonary hypertension. We then outline several tractable targets and pathways relevant to pulmonary hypertension via MDSC regulation. Identifying these MDSC-regulated effectors is part of an ongoing effort to impact the field of pulmonary hypertension research through identification of myeloid compartment-specific therapeutic applications in the treatment of pulmonary vasculopathies.
\end{abstract}

Keywords: pulmonary hypertension (PH); myeloid-derived suppressor cells (MDSC); monocytic-MDSC (Mo-MDSC); polymorphonuclear-MDSC (PMN-MDSC); dendritic cells (DC); macrophages (M $\Phi$ ); arginase 1 (Arg1); inducible nitric oxide synthase (iNOS); C-X-C motif chemokine receptor type 2 (CXCR2)

\section{Introduction}

Myeloid-derived suppressor cells (MDSCs) were initially described as myeloid cells capable of suppressing $\mathrm{T}$ cell proliferation in vitro but are now known as key participants in a number of physiologic and pathophysiologic conditions. Whether granulocytic (most abundantly represented as polymorphonuclear neutrophils) or mononuclear (primarily monocytes), distinct classes of myeloid cells ultimately originate from three simple observations: (1) cell morphology, which is largely undisputed, (2) lineage-tracing, and (3) cell function, a frequent point of contention. MDSCs, and the controversy surrounding this population of leukocytes, are examples of the latter. 
Since their original discovery over a decade ago, discussion of MDSCs remains provocative due to their subgroup phenotypic similarities to granulocytes (polymorphonuclear MDSCs; PMN-MDSCs) and monocytes (monocytic MDSCs; Mo-MDSCs). Nonetheless, in states of sustained inflammation-such as chronic infection and cancer-growth factor, cytokine, and chemokine signaling patterns favor the release into circulation of immature myeloid cells that operatively inhibit acquired immune cell responses and enhance cellular proliferation and angiogenesis [1]. This MDSC signature has been described in a number of pulmonary infectious diseases, including: Pseudomonas and endemic fungal pneumonia [2,3], tuberculosis [4,5], opportunistic Pneumocystis jiroveci pneumonia [6], and influenza [7]. More recently, however, MDSCs have been recognized as playing a critical role in the pathogenesis of other noninfectious lung diseases, such as chronic obstructive pulmonary disease, asthma, and cystic fibrosis [8]. To date, activated MDSCs have been documented in patients with pulmonary hypertension secondary to congenital heart disease, with cell count in peripheral blood strongly correlated with the severity of pulmonary artery pressure elevation [9]. Although a mechanism has yet to be fully developed, we recently demonstrated a potential role for-specifically-PMN-MDSCs in the pathogenesis of pulmonary hypertension related to models of both chronic hypoxia exposure and pulmonary fibrosis [10].

Given the immature state of MDSC-related research, a major point of contention remains the discernment of the characteristics setting apart MDSC subpopulations (Mo-MDSCs and PMN-MDSCs) from their morphologically similar innate immune cells (monocytes and neutrophils, respectively). In humans, the distinction is relatively straightforward. Mo-MDSCs and monocytes are distinguished based upon MHC class II expression; Mo-MDSCs have the phenotype CD11b ${ }^{+} \mathrm{CD} 33{ }^{+} \mathrm{CD} 14^{+}$ CD15 ${ }^{-}$and HLA-DR ${ }^{-}$, whereas monocytes are HLA-DR ${ }^{+}$[11]. PMN-MDSCs and neutrophils share a phenotype $\left(\mathrm{CD} 33{ }^{+} \mathrm{CD} 11 \mathrm{~b}+\mathrm{CD} 14-\mathrm{CD} 15^{+} \mathrm{CD} 66 \mathrm{~b}{ }^{+}\right)$, however, differences in Percoll density gradients easily distinguish neutrophils (high density) from PMN-MDSCs (low density, with suppressive capability) [12]. Furthermore, transcriptomic analysis has revealed specific signatures identifying neutrophils, PMN-MDSCs, and even tumor-associated neutrophils (TANs) [13].

In mice, Mo-MDSCs are defined as CD11b ${ }^{+}$Ly6Chi Ly6G ${ }^{-}$cells with low granularity, discriminated from monocytes by lack of surface markers CD11c and MHC II, and from macrophages by absence of F4/80 [1]. Specific markers, outside of functional assessment, remain elusive in distinguishing murine PMN-MDSCs from granulocytes, except perhaps related to expression of key metabolic enzymes necessary for facilitating immune escape [14].

The goal of this review is to summarize the literature on the role of MDSCs in the pathogenesis of pulmonary hypertension, focusing on the myriad shared molecular and cell-specific pathways involved in both pulmonary vascular remodeling and MDSC regulation.

\section{Pulmonary Hypertension and Myeloid Cell Disorders}

In order to establish the role of a specific circulating cell population, such as MDSCs, in the development of pulmonary hypertension, it is useful to first examine broadly the context of myeloid cells in pulmonary vascular disease. To this end, we survey the occurrence of myeloid cell changes in pulmonary hypertension (primarily pulmonary arterial hypertension, $\mathrm{PAH}$ ), but also examine pulmonary vascular disease in pathologic states of myeloid activation or dysfunction (myelodysplastic syndromes), and-importantly-discuss the effect of stem cell transplantation on disease states associated with lung vessel remodeling.

\subsection{Stem Cell Transplantation and Pulmonary Hypertension}

Hematopoietic stem cell transplantation (HSCT)—a common treatment for malignant hematologic disease-is frequently considered as a contributor to the development of pulmonary hypertension. Support for a potential causal role in pulmonary artery pressure elevation in this condition, however, is confounded by several factors: chemoradiation injury resulting in occlusive vasculopathy [15], pulmonary hypertension associated with bronchiolitis obliterans [16], and pulmonary thromboembolic 
disease complicating the use of some immunobiologic agents, such as the tyrosine-kinase inhibitor dasatinib [17].

Although associated with adverse vasculopathic injuries and employed in the treatment of selective disease states that are mainly rheumatologic, there may be beneficial effects of HSCT on the pulmonary circulation. For example, in patients with systemic sclerosis, autologous HSCT was found to be associated with stabilization of pulmonary hypertension in affected patients [18]. Additionally, a 5-year post-transplant follow-up study of this same patient cohort demonstrated a trend towards improved lung function parameters, such as the diffusing capacity of lung for carbon monoxide (DLCO) [19], while a more recent clinical trial showed that, in patients with scleroderma, stem cell transplantation can prevent the development of pulmonary hypertension [20]. Similar disease remission following HSCT has been noted in patients with pulmonary hypertension secondary to systemic lupus erythematosus [21,22]. Finally, in a case report of a patient with treatment-refractory sickle cell anemia, reversal of precapillary pulmonary hypertension was found upon undergoing haploidentical non-myeloablative peripheral blood stem cell transplantation [23].

In support of a potentially protective role for bone marrow transplant in the treatment or prevention of pulmonary hypertension, multiple animal models have demonstrated that bone marrow-derived cells ameliorate elevated pulmonary pressures. For example, one study using the monocrotaline model of pulmonary hypertension examined the role of endothelial progenitor cell adoptive transfer in the prevention of disease, finding that early administration of cells completely halted the development of pulmonary hypertension, when compared to infusion of normal fibroblasts [24]. Subsequent follow-up research on the use of these endothelial-like cells in small animal models has shown that recruitment and metabolic factors-such as erythropoietin receptor and nitric oxide synthase, respectively-are necessary for the appropriate integration of these cells into the distal arterioles $[25,26]$. These multiple contributory factors may in part explain the disparate findings amongst groups of whether bone marrow-derived cells contribute solely to hypoxia-induced pulmonary hypertension, as opposed to mechanical or chemical-related pulmonary vascular injury and repair $[27,28]$. Regardless, whole bone marrow transplant, after total body irradiation, has been demonstrated to be protective against the pulmonary hypertension phenotype in multiple species, including mice [29], rats [30], and dogs [31]. The most definitive evidence supporting the role of bone marrow-derived cells in the development of pulmonary hypertension and pulmonary vascular remodeling comes from recent studies, in which bone marrow chimeric mice were generated from animals with canonical mutations predisposing them to human $\mathrm{PAH}$, including bone morphogenetic protein receptor type II (BMPR2) [32] and calveolin-1 (Cav1) [33]. Collectively, these data are suggestive of a tissue-specific influence by the myeloid compartment in the initiation and maintenance of some forms of elevated pulmonary pressures.

\subsection{Myelodysplastic Syndromes and Pulmonary Hypertension}

There is a universally poor prognosis associated with the development of elevated pulmonary pressures in the setting of myeloproliferative disorders, a complication affecting roughly $40 \%$ of such patients, as noted in a retrospective chart review [34,35]. Among the reported causes of pulmonary vascular disease, patients exhibit hematopoietic infiltration of pulmonary parenchyma and hypercoagulability, leading to chronic thromboembolic pulmonary hypertension and thrombocytosis [36]. Intriguingly, myelofibrosis appears to be unique among chronic myeloproliferative disorders in its consistent association with elevated pulmonary artery pressure. In one study, compared to patients with chronic myelogenous leukemia and aplastic anemia, those with myelofibrosis alone had significantly greater right-ventricular pathology by echocardiogram assessment [37]. It remains unclear, however, if this association represents a causal relationship, or merely a secondary link between pulmonary hypertension and primary myelofibrosis. The latter conclusion is supported by the lack of reported association between development of pulmonary 
hypertension and the allelic burden of common Janus kinase 2 (JAK2) allelic variant (V617F), which is responsible for many myeloproliferative neoplasms [38,39].

Analogous to the above-described examples, allogenic stem cell transplant was shown to attenuate pulmonary hypertension associated with myelofibrosis [40] in a patient with prohibitive comorbidities and drug-drug interactions precluding use of traditional vasodilator therapies. This case is consistent with what is known regarding chronic myeloproliferative disorders associated with pulmonary hypertension, whereby there are multiple attributable causes described [41], similar to the noted heterogeneous etiologies of pulmonary hypertension after treatment with bone marrow transplant $[42,43]$.

\subsection{Abnormalities in Myeloid Cells in Pulmonary Hypertension}

There is ample evidence describing pulmonary vascular disease, PAH in particular, as a systemic disorder. In particular, PAH is associated with intrinsic alterations in the myeloid compartment. Patients with PAH show evidence of decreased monocyte activation through the inhibition of nuclear factor kappa B cell (NF-kB) signaling, interleukin-6 (IL-6), CC chemokine ligand-3 (CCL3, previously macrophage inflammatory protein 1-alpha), and vascular endothelial growth factor (VEGF) [44]. In addition, they display an enhanced neutrophil inflammatory response to various stimuli that is tempered by in vitro incubation with prostacyclin analogue iloprost [45]. Furthermore, bone marrow-derived proangiogenic progenitor $\left(\mathrm{CD} 34{ }^{+} \mathrm{CD} 133^{+}\right)$cells are elevated in the circulation of PAH patients [46]; interestingly, the subclinical myeloproliferative process is also present in nonaffected family members of PAH patients, and it is associated with an increase in endothelial cell production of hypoxia-inducible factor response element chemokines, such as stromal cell-derived factor 1 (SDF1) [47].

In a landmark study, Asosingh and Erzurum's group elaborated upon the cellular mechanism of pulmonary vascular disease attributed to intrinsic myeloid cell abnormalities [48]. As reported, they first isolated $\mathrm{CD} 133^{+}$bone marrow progenitor cells from patients with PAH and healthy controls, injecting the populations into NOD-SCID mice. They then assessed for differences in right ventricular hypertrophy, pulmonary vascular remodeling, and mortality between groups, finding that only in mice transplanted with cells from patients with PAH did the disease develop. These findings are consistent with others reporting a supporting role of circulating monocytic lineage precursors-alternatively referred to as fibrocytes-in hypoxia-induced large animal models of pulmonary hypertension [49].

Perivascular cellular recruitment—especially of macrophages-has been described in PAH [50], with the process facilitated through a diverse array of mediators, including leukotriene signaling [51], and granulocyte-macrophage colony-stimulating factor (GM-CSF) production [52], in patients that carry a common mutation in BMPR2. Subsequently, the local inflammatory milieu directs a shift from an M1 (inflammatory) to an aberrant M2 (reparative) phenotype, promoting deleterious vascular healing [53]. This is similar across other forms of pulmonary hypertension, where type 2 inflammation is integral to the proliferative vascular response, such as in schistosomiasis-mediated vascular disease [54]. Of relevance to this point, bone marrow-derived mononuclear cells, administered 4 weeks after monocrotaline administration, improved pulmonary hypertension through both increased VEGF expression [55] and inhibition of soluble inflammatory mediators [56]. In contrast, growth factors associated with monocytic expansion, such as GM-CSF, increase inflammatory cell recruitment to the lungs in mice with the BMPR2 mutation, exacerbating pulmonary hypertension [52]. This effect may be attributable to macrophage activation in a paracrine-dependent manner, which mediates local pulmonary vessel smooth muscle cell changes directly [57].

Due to this highlighted function in cellular trafficking and accumulation that is critical to advancement of pulmonary vasculopathies, chemokine receptors play a major role in progression of pulmonary hypertension. $\mathrm{C}-\mathrm{C}$ chemokine receptor 2 (CCR2), the receptor for $\mathrm{CC}$ chemokine ligand 2 (CCL2), is a cell surface signaling protein which facilitates the egress of mononuclear cells from the bone marrow into the circulation, as well as the rolling, adhesion, and diapedesis of circulating 
cells into the lung vascular bed. CCR2-deficient mice have an expected decrease in recruitment of inflammatory monocytes to the lung during chronic hypoxic stress, associated with worsening of pulmonary hypertension [58].

Polymorphonuclear neutrophils—especially direct neutrophil interactions with lymphocyteshave been shown to be important in the development of pulmonary hypertension. An elevated neutrophil-to-lymphocyte ratio in the peripheral blood is associated with a poor prognosis in pulmonary hypertension patients [59], speculated to be due, in part, to neutrophil extracellular trap promotion of inflammatory angiogenesis [60]. These findings are consistent with established experimental data derived from sheep and rabbit models of disease, which demonstrate that granulocyte depletion is protective against pulmonary hypertension [61,62]. A similar effect on lung disease is seen in mice with antagonism of a chemokine receptor, $\mathrm{C}-\mathrm{X}-\mathrm{C}$ chemokine receptor 2 (CXCR2), expressed predominantly on circulating granulocytes and endothelial progenitor cells. For example, in BMPR2 mutant mice-with deletion of BMPR2 in only the vascular endothelium-treatment resulted in protection against pulmonary hypertension progression $[63,64]$. This protection was strongly associated with a decrease in lung myeloperoxidase and vascular barrier permeability. Interestingly, neutrophil populations were relatively unaffected by CXCR2 inhibition, suggesting another cell type of interest contributing to vascular disease, such as PMN-MDSC. Yet, a more recent report has described a decrease in neutrophils in PAH patients' lung tissue samples associated with a concomitant increase in T cell subsets, including $\gamma \delta$ cells, and plasmacytoid dendritic cells [65], providing a potential innate-to-adaptive immune system link in disease progression.

Functionally, local differentiation or maturation of myeloid cells influences the development of pulmonary hypertension to a larger degree than simple trafficking to the pulmonary vasculature of various bone marrow-derived cell populations. Although myeloid cells have been shown to worsen the development of pulmonary vascular remodeling in response to chronic hypoxia and monocrotaline injection, inhibiting downstream maturation of myeloid cells within tissue can protect against this outcome [66]. While this phenomenon is thought to be mitigated in large part by the cellular cross-talk between immune and endothelial cells, maturation of myeloid cells is also likely to influence signaling with alternative cell types, including T lymphocytes, in the lung perivascular space. Such accumulation and activation of the adaptive immune system represents a potential feed-forward mechanism in the lungs of diseased animals, and potentially humans; increased myeloid cell trafficking leads to low-grade adaptive immune cell inflammatory signaling, attendant peripheral cell recruitment, and worsening of disease [67]. This may in part explain how soluble factors, such as IL-6, contribute to T helper 17 cell $\left(\mathrm{T}_{\mathrm{H}} 17\right)$ activation and the M2-like macrophage response in hypoxia-induced pulmonary hypertension $[53,68]$, as discussed below.

\section{Myeloid-Derived Suppressor Cells and Pulmonary Hypertension}

Numerous myeloid cells likely contribute to the development of pulmonary hypertension. Though there is an acknowledged role for a diverse number of cell types in disease pathogenesis, including eosinophils [69], fibrocytes [70], dendritic cells [65], endothelial progenitor cells (both early [71] and late [72,73]), and mast cells [74], the remainder of this analysis focuses exclusively on the role of MDSCs in pulmonary hypertension. Specifically, attention is drawn to shared intracellular (molecular) and intercellular (cell-cell) mechanistic pathways between pulmonary hypertension and MDSC-mediated disease development (refer to Figure 1 and Table 1 for a detailed summary). Finally, the MDSC contribution to metabolic changes within the tissue microenvironment, including effects on vascular endothelial and smooth muscle cells, is also considered. 


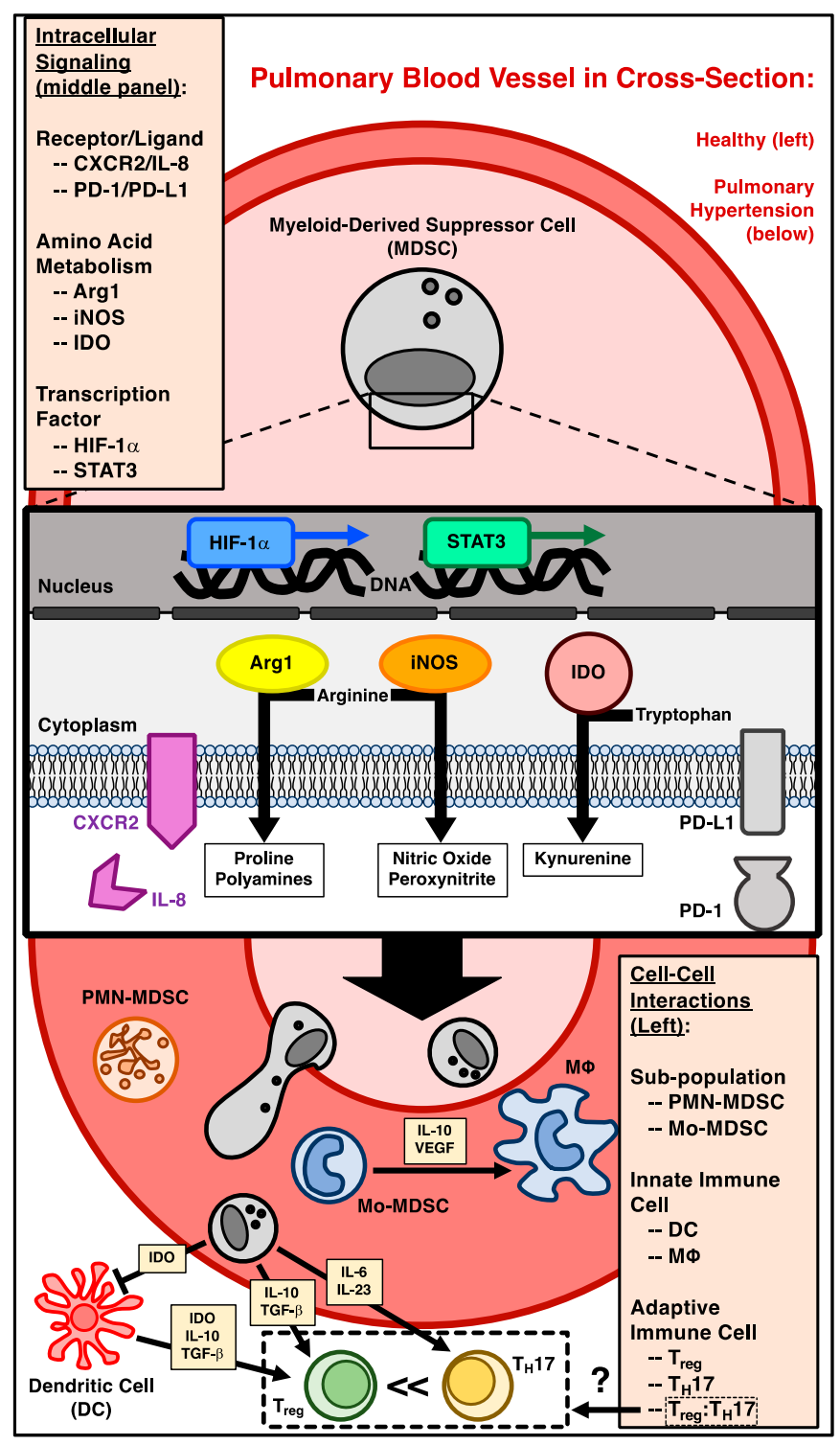

Figure 1. Illustration detailing potential myeloid-derived suppressor cell (MDSC) contributions to pulmonary vascular remodeling and development of pulmonary hypertension (PH). Displayed are proposed intracellular and intercellular MDSC-mediated mechanisms in the development of $\mathrm{PH}$. These include, although are not limited to: receptor/ligand interactions (CXCR2/IL-8 and PD-1/PD-L1), regulation of amino acid metabolism favoring cellular proliferation and aberrant wound repair (arginine via Arg1 and iNOS, and tryptophan through IDO), and transcription factor stabilization and activation (HIF-1 $\alpha$ and STAT3). Cell-cell interactions include molecular cross-talk between: subpopulations of MDSC (PMN-MDSC and Mo-MDSC), innate immune cells (M $\Phi$ and DC), and-finally-adaptive immune effector cells (Treg and $\mathrm{T}_{\mathrm{H}}$ 17). The disarrangement of the latter cell groups' ratio (Treg: $\mathrm{T}_{\mathrm{H}} 17$ ) is likely of particular importance in influencing the microenvironment favoring pulmonary vascular remodeling and PH. Abbreviations: CXCR2 (C-X-C motif chemokine receptor type 2); IL-8 (interleukin 8); PD-1 (programmed cell death protein-1); PD-L1 (programmed death-ligand 1); Arg1 (arginase-1); iNOS (inducible nitric oxide synthase); IDO (indoleamine-pyrrole 2,3-dioxygenase); HIF-1 $\alpha$ (hypoxia-inducible factor-1 alpha); STAT3 (signal transducer and activator of transcription 3); PMN-MDSC (polymorphonuclear MDSC); Mo-MDSC (monocytic MDSC); DC (dendritic cell); $\mathrm{M} \Phi$ (macrophage, particularly $\mathrm{M}_{2}$-polarized); Treg (regulatory $\mathrm{T}$ cell); $\mathrm{T}_{\mathrm{H}} 17$ (T helper 17 cell); IL-10 (interleukin 10); VEGF (vascular endothelial growth factor); IL-6 (interleukin 6); IL-23 (interleukin 23); TGF- $\beta$ (transforming growth factor beta). 


\subsection{Molecular Mechanisms}

\subsubsection{C-X-C Motif Chemokine Receptor Type 2 (CXCR2)}

As described earlier, the studies by Burton and Budd [63,64] define a significant role for CXCR2-mediated accumulation of circulating leukocytes in pulmonary hypertension. Initially exploring the link between accrual of leukocytes within the lung and subsequent vascular injury repair in BMPR2 heterozygous null mouse models, they demonstrated that loss of BMPR2 expression within the vascular endothelium leads to increased susceptibility to pulmonary inflammatory stimulus through worsening vascular barrier permeability [63]. They then went on to show that, with administration of a CXCR1/2 inhibitor, not only was accumulation of leukocytes attenuated, but the pulmonary hypertensive response was corrected as well [64]. It remains to be elucidated, however, which tissue-specific expression of CXCR2-myeloid, endothelial, or epithelial cell-is most contributory to disease progression. Of relevance to this point, at least one additional study has demonstrated a protective role for CXCR2 overexpression in endothelial cells in the monocrotaline rat model, with marked decrease in neutrophil accumulation to the lung and decreases in interleukin-8 (IL-8) expression within the lung [75].

As mentioned, we have demonstrated an association between decreased MDSC homing to the inflamed lung and attenuation of pulmonary vascular remodeling with administration of a selective CXCR2 inhibitor. There are additional supportive data, generated primarily from the cancer and autoimmunity literature, that establishes a role for CXCR2-mediated trafficking and activation in PMN-MDSC-mediated pathology. For example, in an inflammatory colitis and colon cancer model, CXCR2 null mice were protected against development of disease, with tumor progression restored only after adoptive transfer of activated MDSCs [76]. In another model examining pancreatic cancer, it appeared that targeting CXCR2 expression by immune cells was protective against malignant progression and metastasis, primarily through promotion of effector $\mathrm{T}$ lymphocyte- $\mathrm{CD} 8{ }^{+} \mathrm{T}$ cell-activity [77]. The same phenomenon has been observed in bladder cancer [78].

Although CXCR2 is expressed highly by circulating neutrophils in relevant models of comparison, such as cancer, it is primarily and functionally associated with upregulation on PMN-MDSCs [12]. Additionally, other cell-surface chemokine receptors commonly expressed by Mo-MDSC, such as CCR2 and CX3CR1, are highly expressed in circulating immune cells accumulating within the lungs of mice with chronic hypoxia-induced pulmonary hypertension [79]. A direct role, however, for secreted CCR2 and CX3CR1 ligands in regulating the hemodynamic changes, beyond recruitment of inflammatory monocytes and indirect influence on pulmonary artery smooth muscle cell hyperproliferation, remains unproven [80].

\subsubsection{Arginase-1 (Arg1)}

In the original report by Yeager and colleagues, MDSCs detected in the peripheral circulation of patients with pulmonary hypertension were noted to have increased Arg1 transcripts, consistent with a detected increase in urea activity from isolated patient samples [9]. Relevant to multiple contributory pathways involved in pulmonary hypertension, arginase is a required initial step in the polyamine production, ornithine flux, and proline synthesis necessary for cellular proliferation and collagen formation. Importantly, arginase activity is known to be elevated in PAH patients with an increase in both arginine clearance and ornithine flux, without alterations in citrulline flux, de novo arginine synthesis, or nitric oxide synthesis [81]. Furthermore, experimental hypoxia is known to upregulate arginase activity via hypoxia-inducible factor-2 alpha (HIF-2 $\alpha$ ), with decreased pathologic signs of hypoxia-induced pulmonary vascular remodeling noted upon deletion of Arg1 in pulmonary vascular endothelial cells [82]. These data are consistent with the recent detection of a protective SNP variant in Arg1 that results in decreased arginase activity against development of pulmonary hypertension in at-risk infants with bronchopulmonary dysplasia [83]. The potential therapeutic application of this finding has been demonstrated in rats exposed to monocrotaline, where pharmacologic arginase was 
inhibited by administration of the small molecular inhibitor N $\omega$-hydroxy-nor-L-arginine (nor-NOHA), ameliorating pulmonary hypertension and diminishing lung tissue remodeling [84].

Although recent evidence suggests that Arg1 is neither inherently expressed in MDSCs nor required for MDSC-mediated inhibition [85], Arg1 expression by MDSCs is widely considered the essential feature by which these cells mediate their immunosuppressive role, by mediating arginine depletion and downstream $\mathrm{T}$ cell receptor downregulation [86]. This is thought to occur mainly in PMN-MDSCs in common cancer models $[87,88]$. Thus, it is intriguing to hypothesize that PMN-MDSC arginase activity may contribute to pulmonary vascular remodeling through the cooperative interaction of two distinct mechanisms: pro-collagen production and perivascular fibrosis, and by downstream effects on T lymphocyte cross-talk.

\subsubsection{Inducible Nitric Oxide Synthase (iNOS)}

With respect to arginine metabolism, one must consider not only arginase activity, but also substrate use by the various members of the nitric oxide synthase (NOS) family. While endothelial NOS (eNOS) and the vasodilatory properties of nitric oxide are well known to influence pulmonary hypertension [89], only recently has it been demonstrated that myelocytic NOS expression may be necessary in order to prevent pulmonary hypertension in a murine chronic-hypoxia model [90]. In this study, chimeric mice generated from transplanting NOS-deficient bone marrow into wild-type recipients experienced worsened pulmonary hypertension compared to mice transplanted with wild-type bone marrow. Additionally, in the analysis of nitric oxide levels in the bronchoalveolar lavage fluid of patients with idiopathic pulmonary fibrosis, the group found an inverse correlation between levels of the metabolite and pulmonary artery systolic pressures in patients. Adding to the credibility of the findings, these data are consistent with a previous report examining pulmonary hypertension secondary to emphysema [91]. In the latter study, inhibition of iNOS specifically—with an attendant decrease in tissue peroxynitrite concentration-was found to protect against the development of pulmonary hypertension secondary to chronic tobacco smoke exposure. Furthermore, in mice transplanted with bone marrow cells lacking iNOS, pulmonary hypertension developed as expected compared to the control group, proving the myeloid compartment as necessary for disease progression.

Related to these reports, peroxynitrite and free radical maintenance by iNOS is one of the primary mechanisms that MDSCs are shown to directly inhibit $\mathrm{T}$ cell function in a localized inflammatory response, such as tumor growth [92]. In a melanoma model, this is known be a VEGF-dependent process. Increased levels of VEGF enabled immune suppression by increasing signal transducer and activator of transcription 3 (STAT3) activation, and reactive oxidative species production, in recruited MDSCs. This established a positive feedback loop of MDSC recruitment and activation. The feed-forward mechanism was interrupted by iNOS inhibitor L-N ${ }^{6}$-(1-iminoethyl) lysine dihydrochloride (L-NIL), which normalized VEGF levels and negated the immunosuppressive capabilities of MDSCs [93]. A similar phenomenon is thought to influence the pathogenesis of pulmonary hypertension [94].

\subsubsection{Indoleamine-Pyrrole 2,3-Dioxygenase (IDO)}

IDO-mediated tryptophan metabolism is closely related to arginine regulation and regulates the immunosuppressive capabilities of myeloid cells [95]. In addition, endothelial IDO ameliorates experimentally induced pulmonary hypertension via paracrine proapoptotic signaling with pulmonary artery smooth muscle cells [96]. In patients with $\mathrm{PAH}$, however, metabolic profiling has identified tryptophan metabolites to be associated with right ventricular and pulmonary vascular dysfunction [97]. In particular, serum kynurenine-a primary IDO-tryptophan metabolite-is significantly elevated in PAH patients. This suggests potential IDO-metabolite resistance in these patients, given that kynurenine opposes pulmonary artery vasoconstriction via nitric oxide-mediated vasodilation, acutely decreasing mean pulmonary artery pressure [98]. 
Indirectly related, transcription factor-dependent IDO expression mediates the immunosuppressive effect of MDSCs in a breast cancer model, with IDO blockade leading to the inhibition of effector T cell response and improvement in disease-related outcomes [99,100]. Unlike previously discussed mechanisms, however, IDO-associated immune escape is predominantly thought to be related to Mo-MDSC pathology (CD14 ${ }^{+}$HLA-DR ${ }^{-}$peripheral cells in patients with cancer) [101], although this characterization remains a point of debate. Related to the evolving nomenclature of the immune cell population in patients with $\mathrm{PAH}$, a group has recently characterized a novel "fibrocytic MDSC" [102]. These primarily regulate Treg cells through direct contact-mediated IDO upregulation. Other investigators have similarly broadened the role for tryptophan metabolism in MDSC-related immune escape, arguing that it is tumor-expressed IDO that is the primary mechanism regulating immunosuppression within the tumor/tissue microenvironment [103]. It remains to be determined if production of IDO and IDO-tryptophan metabolites by MDSCs or pulmonary vasculature meaningfully contributes to the development of pulmonary hypertension.

\subsubsection{Signal Transducer and Activator of Transcription 3 (STAT3)}

Prosurvival proliferative transcription factor activation is implicated in several generic pathologic processes. The STAT family, and STAT3 in particular, are broadly implicated in the pathogenesis of pulmonary hypertension in animal as well as human tissue models. To date, at least one group has firmly demonstrated that inhibition of STAT3-related signaling molecule Pim1 reverses pulmonary vascular remodeling in the rat monocrotaline model [104]. The same investigators also showed that hormone-responsive pulmonary hypertension requires a functional STAT3 signaling axis [105]. Related to this is MDSC regulation through STAT, which has been found to be important in other systemic inflammatory models of disease, such as septic shock, where PMN-MDSC-associated autophagy is regulated directly by STAT3 phosphorylation [106], leading to worsened outcomes. These findings highlight the shared pathways between pulmonary vasculopathies and cancer pathobiology, and they open the door to potential pharmacologic agents available to target STAT-mediated pathways [107]. Many prospective drugs affecting STAT signaling have already undergone intense study as potential therapies targeting MDSC-mediated immune suppression [108], directly applicable to the field of pulmonary hypertension research.

\subsubsection{Hypoxia-Inducible Factor (HIF)}

Similar to the regulation of JAK-STAT, acute and chronic changes in the lung microenvironment (such as $\mathrm{pH}$, temperature, and oxygen content) can impact another evolutionarily ancient transcription factor, hypoxia-inducible factor (HIF). This highly conserved protein is stabilized in response to predominantly hypoxic and/or metabolic stress, with both of its main isoforms being implicated in the development of chronic hypoxia-induced pulmonary hypertension: HIF-1 $\alpha$ [109] and HIF-2 $\alpha$ [110]. Although a thorough review of tissue-specific HIF regulation in lung vascular disease is beyond the scope of the current work, it is relevant to the discussion at hand to mention a major recent discovery in myeloid cell HIF expression's contribution to pulmonary hypertension. In an elegant series of experiments, Sheikh and colleagues demonstrated that, in a cell autonomous manner, myeloid cells transdifferentiate into, or fuse with, distal pulmonary arteriole smooth muscle cells during hypoxic exposure; it follows that with deletion of a key hypoxia-response element gene in myeloid cells, the pathologic vessel changes are attenuated [111]. This is important, as HIF- $1 \alpha$ has been shown to be a primary driver of MDSC differentiation and function, with a shift toward a tumor-associated macrophage phenotype (discussed in the Cellular Mechanisms section, below) phenotypic differentiation and activation [112-114].

Mediation of such cell-cell interactions by HIF is not limited to a relationship between MDSC and other innate immune cell populations. HIF similarly regulates programmed cell death protein-1 (PD-1)/programmed death-ligand 1 (PD-L1) signaling that functions principally in MDSC and CD8 + effector $\mathrm{T}$ cell direct interactions in patients with obstructive sleep apnea, a common cause of 
secondary pulmonary hypertension [115]. Such immune checkpoint inhibitors, including PD-L1, are often hypoxia-response element genes themselves. Thus, experimentally blocking these targets with available immunobiologic agents in chronic hypoxia models leads to increased $\mathrm{T}$ cell activation, chiefly due to decreased MDSC activity and function [116]. Therefore, the application of these techniques to pulmonary hypertension research is potentially beneficial.

\subsection{Cellular Mechanisms}

\subsubsection{Dendritic Cells (DCs)}

In patients with PAH, immature DCs-as well as activated CD209 ${ }^{+}$DCs-accumulate in the remodeled pulmonary perivascular space $[117,118]$. The latter study described an increase in activated classical myeloid-derived DCs and nonclassical plasmacytoid DCs derived from the lungs of PAH patients. Accordingly, it remains the predominant thought that DCs and monocytes are actively recruited to the pulmonary vascular microenvironment in the chronic hypoxia model of pulmonary hypertension [119]. This finding is most consistent with the fact that PAH patients also display a decrease in circulating myeloid DCs and monocyte-derived DCs, compared to healthy control subjects [120].

Tolerogenic DC-like cells, which suppress $\mathrm{T}$ cell function, have been reported to differentiate from Mo-MDSCs in a mouse model of interstitial lung disease [121]. In cancer models, Mo-MDSCs are thought to undergo a transition to antigen-presenting DC-like cells as part of the increased response to tumor neoantigen and subversion of immune escape [122]. Less in known about direct MDSC-to-DC cross-talk [123], but a well-described consequence of increased MDSC density is an inverse effect on maturity of physically adjacent DCs, an intriguing potential mechanism-and therapeutic application-relating to the presence of immature DCs in patients with PAH [124]. MDSCs reproducibly influence DCs in manner that decreases antigen uptake-with subsequent decreased T cell activation - and skews to an anti-inflammatory cytokine milieu [125,126]. Ultimately, this may prove to be the most important influence on the vascular remodeling potential of MDSCs, as decreased DC production of IL-23 leads to lack of $\mathrm{T}_{\mathrm{H}} 17$ induction [127], skewing the ratio of Treg: $\mathrm{T}_{\mathrm{H}} 17$ in a potentially deleterious direction.

\subsubsection{Macrophages}

Macrophages are unique in that they are considered the front line of innate immune cells acting in specialized roles, on a spectrum of activities, in response to a panoply of disorders [128]. Macrophages predominantly exist as either derived from recruited "inflammatory" monocytes that undergo transition to macrophages, or as tissue "resident" macrophages that remain in a relatively quiescent state, sensing the immediate environment until provoked by an inflammatory stimulus [129]. As is the case with DCs, macrophages have long been implicated in the immunohistologic pathogenesis of pulmonary hypertension, with large amounts of perivascular macrophages noted in lung samples from patients with PAH, compared to healthy controls [130]. Experimentally, early monocyte/macrophage recruitment is required for hypoxia-induced pulmonary vascular remodeling [131]. BMPR2 mutations contribute to this aberrant trafficking in either an endothelial-specific manner [52] or independently through macrophage BMP pathway dysfunction [57]. Subsequent influence on the polarization of macrophages in the lung remains important, as a shift to an IL-10 productive phenotype has been shown to be protective against hypoxia-induced pulmonary hypertension [80]. This phenotypic plasticity is the primary focus of much of the macrophage-related research in pulmonary circulation research. Currently, the field has moved beyond the earlier described characterization of macrophages as either "inflammatory" (M1) or "repair" (M2), to a distinct profibrotic/proinflammatory amalgam [132].

A similar shift from the M1/M2 dichotomy is a well-defined response to MDSC tumor infiltration, first described in oncologic studies, therefore carrying the moniker "tumor-associated macrophage" 
(TAM) [133]. In isolation, experimental data craft a convincing argument that the relationship between MDSCs and TAMs or TAM-like cells may be potentially beneficial in application to pulmonary hypertension: the MDSC-to-TAM cross-talk facilitates an increase in IL-10 production, a subsequent decrease in IL-12 secretion, and an overall activation of FoxP3 ${ }^{+}$Treg populations [134]. Taken together, however, the cumulative effect of direct MDSC immune suppression strategies (Arg1, iNOS, and IDO) could simply overpower even the most robust indirect macrophage-mediated protective response to ongoing lung tissue injury. Such an effect may favor progression of pulmonary vascular disease. Alternatively, IL-10 may downregulate MHC class II presentation to the cell surface, leading to specific unresponsiveness of $\mathrm{T}$ cells to potential alloantigens involved in the development of pulmonary hypertension [135]. More studies are required to make definitive conclusions regarding this topic.

\subsubsection{Regulatory $\mathrm{T}$ Cells (Treg) and $\mathrm{T}$ helper 17 Cells $\left(\mathrm{T}_{\mathrm{H}} 17\right)$}

Regulation of $\mathrm{T}$ lymphocyte populations in patients with pulmonary hypertension is an intriguing area of research in light of known alterations in circulating T cell subsets. An increase in circulating $\mathrm{CD}^{+}{ }^{+}$effector T cells and elevation in CD4 ${ }^{+} \mathrm{FOXP}^{+}$(Treg) cells in patients with PAH [136] have been corroborated in genetic models of pulmonary hypertension [137]. As subsequent studies have shown, while absolute number of individual T-cells may be increased, there is evidence that this may be due in part to a global decrease in T regulatory cell function in those with PAH [138]. This finding illustrates some of the difficulty in interpretation and translation of these complicated findings to humans with disease, as seemingly conflicting reports have described an elevation in functional Treg in those with PAH [139]. Nonetheless, it is clear that complete deficiency in T cells predisposes individuals to pulmonary hypertension, as evidenced in athymic nude rats, which develop pulmonary hypertension solely in response to the VEGF receptor block (SU5416) in the absence of usual co-stimuli hypoxia [140]. The picture becomes even more complicated when, in examining in some models of disease, depletion of $\mathrm{CD} 4{ }^{+} \mathrm{T}_{\mathrm{H}} 2$ cells alone ameliorates pulmonary arterial muscularization [141], while in other studies, $\mathrm{CD} 4{ }^{+}$cell adoptive transfer causes worsening pulmonary hypertension in response to ongoing endothelial injury [142].

Potentially reconciling these disparate findings, more recent data have shown that immune reconstitution of T cell-deficient rats with functional Treg prevents pulmonary hypertension [143]. There is also evidence, however, to suggest that this may reflect the Treg: $\mathrm{T}_{\mathrm{H}} 17$ cell balance. Influencing this ratio directly, patients with PAH are noted to have an increase in circulating IL-17 compared to controls [144], perhaps related to tryptophan metabolism [145], although this may simply be present in a subset of patients [146]. Still, these data assume that Treg in patients with PAH are functionally equivalent to those from controls; there is convincing evidence to suggest that there is not only Treg dysfunction in pulmonary hypertension [147], but amplified $\mathrm{T}_{\mathrm{H}} 17$ activation [68]. In reference to the above discussion on the role of macrophages and DCs in pulmonary hypertensive changes, the resulting effects on $\mathrm{T}$ cells may also influence accumulation of innate immune cell populations in the perivascular space, leading to increased activation of mediators that can either worsen or improve pathologic pulmonary artery remodeling [67], depending on context.

MDSCs, by definition, regulate $\mathrm{T}$ cell proliferation and are known to cause an increase in Treg at the expense of $\mathrm{T}_{\mathrm{H}} 17$ cells [148]. In autoimmunity, though, the opposite has been described: MDSCs, primarily PMN-MDSCs, are associated with an absolute decrease in Treg and an increase in $\mathrm{T}_{\mathrm{H}} 17$ activity, an imbalance that is restored upon MDSC depletion [149] through primarily Arg1-dependent mechanisms [150]. Treg can also recruit and activate MDSCs, although if the function of either is impaired, an increased number of both cell types may accumulate in the tissue and in circulation [103], contributing to disease. Finally, there are a number of ways that identified MDSC and T cell populations may contribute to pulmonary hypertension through many of the previously discussed metabolic or signaling pathways, including Arg1, iNOS, STAT3, and PD-L1/2 activation [151]. Future research will require in-depth study of each of these mediators in relation to adaptive immune system changes in the development of pulmonary hypertension. 
Table 1. Comparison of potential effectors in disease pathogenesis of pulmonary hypertension (PH) and myeloid-derived suppressor cell (MDSC) mediated pathology.

\begin{tabular}{|c|c|c|}
\hline $\begin{array}{c}\text { Molecular or Cellular } \\
\text { Effector }\end{array}$ & Pulmonary Hypertension [ref.] & $\begin{array}{l}\text { Myeloid-Derived Suppressor } \\
\text { Cells (MDSCs) [ref.] }\end{array}$ \\
\hline CXCR2/IL-8 & 仓 $[63,64]$ & 仓 $[10,76-79]$ \\
\hline Arg1 & 仓 $[9,82-85]$ & ת [86] and 仓 [87-89] \\
\hline iNOS & 仓 $[91,92,95]$ & 仓 [99] \\
\hline IDO & ป [97-99] & 仓 [100-103] \\
\hline STAT3 & 仓 $[105,106]$ & 仓 [107] \\
\hline HIF & 仓 [110-112] & 仓 $[116,117]$ (via PD-1/PD-L1 axis) \\
\hline DC & 仓 [118-122] & 仓 [122-127] (immature DC) \\
\hline $\mathrm{M} \Phi$ & 仓 $[52,57,81,131]$ (M1 phenotype) & 仓 $[135,136]$ (M2/TAM phenotype) \\
\hline Treg & Љ $[139,141,144,148]$ 仓 $[137,138,140]$ & Л $[150,151]$ 介 $[104,149]$ \\
\hline $\mathrm{T}_{\mathrm{H}} 17$ & 仓 $[68,145,146]$ & ת [149] and 仓 $[150,151]$ \\
\hline
\end{tabular}

Abbreviations: CXCR2 (C-X-C motif chemokine receptor type 2); IL-8 (interleukin 8); Arg1 (arginase-1); iNOS (inducible nitric oxide synthase); IDO (indoleamine-pyrrole 2,3-dioxygenase); STAT3 (signal transducer and activator of transcription 3); HIF (hypoxia-inducible factor); PD-1 (programmed cell death protein-1); PD-L1 (programmed death-ligand 1); DC (dendritic cell); M $($ macrophage, either M1 [inflammatory] or M2 [reparative] polarized); TAM (tumor-associated macrophage); Treg (regulatory T cell); $\mathrm{T}_{\mathrm{H}} 17$ (T helper 17 cell).

\subsection{MDSCs and Metabolism}

Many of the thus far described molecular pathways and recruited—or transformed-immune cells point to a common MDSC influence on metabolism, with resulting phenotypic changes to the tissue microenvironment in either tumor stroma (in the case of malignancy) or, potentially, endothelial and smooth muscle cells (related to pulmonary hypertension). MDSCs are known to accelerate cancerous growth and, in particular, increase associated epithelial-to-mesenchymal transition through several soluble secreted factors [152]. Within the tumor microenvironment, these changes are fostered by increased oxidative phosphorylation and a shift to aerobic glycolysis as the primary means of energy production (the Warburg effect). This glycolytic shift further drives the increase in immunosuppressive capabilities of MDSCs [153]. Tumor-infiltrating MDSCs also increase fatty acid uptake and oxidation, leading to an increase in the oxygen consumption rate, influenced by local hypoxia and lactic acid accumulation [154]. The process is coordinated in large part by HIF stabilization and Arg1 expression, as previously discussed.

Through HIF signaling, silent mating type information regulation 2 homolog 1 (sirtuin 1, or SIRT1) - a critical sensor of energy homeostasis—is a primary driver of MDSC differentiation, with deficiency leading to a M2 polarized state. The resulting TAM phenotype is associated with decreased glycolytic activity [155]. Importantly, SIRT1 can serve as a master translator during propagation of acute and chronic inflammatory responses [156]. In support of this concept, mice without myeloid sirtuin 1 display an M1 inflammatory phenotype and delayed progression of tumor growth [155]. Such cross-talk may contribute to transcriptional level control of vascular endothelial proliferation and angiogenesis by niche MDSCs [157], which have previously been shown to be necessary for development of PH [158]. Similar cell-cell communication may also explain why myofibroblasts are known to promote differentiation of MDSC—-through signaling proteins S100A8/A9, IL-6, and IL-8-into TAM-like cells [159]. Interestingly, MDSC-derived fibrocytes are promoted by transcription factor Krüppel-like factor 4 (KLF4) during tumor metastasis, boosting tumor growth as they adopt the cell fate [160]. Comparable smooth muscle cell progenitor cells prime muscularization of pulmonary arteries in hypoxic pulmonary hypertension [161], while endothelial cell-derived KLF4 can modulate hyperproliferative vessel changes in pulmonary vascular remodeling [162].

Metabolic changes in the pulmonary arterial tissue bed, related to the development of pulmonary hypertension, have been extensively summarized previously [163,164]. Recently, however, detailed layered transcriptomic and metabolomic analysis of human pulmonary microvascular endothelial cells expressing BMPR2 mutations have described a novel decrease in energy utilization through the 
Krebs cycle in affected tissue, similar to pathophysiology described in the cancer literature $[165,166]$. Comparable changes have also been described in smooth muscle cells [167]. Therapeutic applications related to these findings remain in the nascent stage, as much more research is required in the field. For example, although SIRT1 expression in immune cells can lessen unregulated cellular growth, resveratrol-a sirtuin 1 agonist-decreases pulmonary hypertension in the rat monocrotaline model [168], and others [169], in a pulmonary artery smooth muscle cell-specific manner [168].

\section{Strategies for Therapeutic Targeting of MDSCs in Pulmonary Hypertension}

Due to the important role MDSCs play in tumor-induced immunosuppression, these cells could be a promising target for therapy in pulmonary hypertension (refer to summary Table 2). Perhaps most relevant to this discourse is the application of a drug class already in widespread use for patients with pulmonary hypertension-phosphodiesterase-5 inhibitors. Used primarily as a vasodilatory agent, sildenafil is also known to decrease MDSC Arg1 and iNOS expression, leading to decreased immunosuppressive capabilities; increased $\mathrm{CD} 8{ }^{+} \mathrm{T}$ cell activation; and reduced tumor metastasis in several cancer models [170-172]. Likewise, Tadalafil improves tumor-specific and nonspecific inflammatory responses through decreased immunosuppressive action in patients with either head and neck squamous cell carcinoma or multiple myeloma $[173,174]$. Since this drug class is already a staple of treatment for pulmonary hypertension, future research should look specifically at combining phosphodiesterase- 5 inhibitors with alternative MDSC targets, a portion of which are discussed below.

Table 2. Potential therapies targeting myeloid-derived suppressor cell (MDSC) in treatment of pulmonary hypertension $(\mathrm{PH})$.

\begin{tabular}{|c|c|c|}
\hline Drug(s) & Mechanism or Pathway of Action & Expected Outcome \\
\hline Sildenafil Tadalafil & $\begin{array}{c}\text { Phosphodiesterase- } 5 \text { inhibitor; } \\
\text { downregulate Arg1 and iNOS } \\
\text { expression in MDSC }\end{array}$ & $\begin{array}{l}\text { In addition to vasodilatory effects, inhibits } \\
\text { MDSC-mediated immunosuppression }\end{array}$ \\
\hline $\begin{array}{l}\text { All-Trans Retinoic } \\
\text { Acid (ATRA) }\end{array}$ & Retinoic acid signal transduction & $\begin{array}{l}\text { Differentiation of MDSC into } \\
\text { macrophages and DC, and decrease } \\
\text { collagen deposition }\end{array}$ \\
\hline AZD9150 & $\begin{array}{l}\text { STAT3 antisense oligonucleotide } \\
\text { inhibitor }\end{array}$ & $\begin{array}{l}\text { Inhibition of MDSC immunosuppressive } \\
\text { activity and restoration of } \mathrm{T} \text { cell function }\end{array}$ \\
\hline Metformin Phenformin & Antidiabetic drug of biguanide class & $\begin{array}{l}\text { Blocks accumulation of MDSC and } \\
\text { enhances effect of PD-1 blockade }\end{array}$ \\
\hline $\begin{array}{l}\text { Nivolumab } \\
\text { Pembrolizumab } \\
\text { Atezolizumab }\end{array}$ & $\begin{array}{l}\text { Monoclonal antibodies directed } \\
\text { against immune checkpoint inhibitors } \\
\text { PD-1 or PD-L1 }\end{array}$ & $\begin{array}{c}\text { Decreased T cell exhaustion, arrest, and } \\
\text { anergy }\end{array}$ \\
\hline AZD5059 & CXCR2 antagonist & $\begin{array}{l}\text { Decreased MDSC trafficking to site of } \\
\text { inflammation and injury }\end{array}$ \\
\hline
\end{tabular}

Abbreviations: CXCR2 (C-X-C motif chemokine receptor type 2); Arg1 (arginase-1); iNOS (inducible nitric oxide synthase); STAT3 (signal transducer and activator of transcription 3); PD-1 (programmed cell death protein-1); PD-L1 (programmed death-ligand 1); DC (dendritic cell).

Blockade of retinoic signal transduction by all-trans retinoic acid (ATRA) induces differentiation of MDSCs to either macrophages or DCs [175], leading to a reduction of MDSC frequencies and improved survival in patients with cancer $[176,177]$. Importantly, ATRA has been shown to decrease collagen deposition in the rat monocrotaline model of pulmonary hypertension [178]. Decreased muscularization of resistant pulmonary arteries has also been demonstrated with ATRA administration in this model [179], although not always associated with a decrease in the pulmonary hypertension phenotype [180].

Since STAT3 is a primary regulator of MDSC-mediated immune escape, inhibition of this transcription factor is an attractive target for the treatment of pulmonary vascular disease. As a logical consequence of this rationale, myeloid-specific targeting of STAT3, through decoy oligonucleotide administration, has already been shown to be successful in the treatment of acute myeloid leukemia in a 
preclinical model of disease [181]. Additionally, AZD9150, a next-generation antisense oligonucleotide inhibitor of STAT3, has already been tested in a phase I clinical trial of patients with lymphoma and lung cancer [182]. These therapies may prove to be especially helpful in combination with other drugs that target the STAT3 pathway shown to have efficacy in pulmonary hypertension management, such as dehydroepiandrosterone (DHEA) [105].

Notably, studies on PD-L1 in pulmonary hypertension development have previously focused on the role of effector T cells and endothelial cells [183], whereas little is known about the role of MDSCs. More recently, the combination of MDSC targeting with immune checkpoint inhibitor treatment has been applied effectively to several preclinical tumor models and cancer patients. An example of this combinatory approach that is relevant to pulmonary hypertension research is the use of PD-1 blockade with phenformin, an antidiabetic drug from the biguanide class. In one study, phenformin was able to enhance the effect of immune checkpoint inhibition, as evidenced by an increase in CD8 ${ }^{+} \mathrm{T}$ cell infiltration in a melanoma model [184]. Although biguanides have previously been associated with metabolic acidosis-induced pulmonary vasoconstriction [185], more recent evidence has demonstrated protection against pulmonary hypertension development by another drug in the class, metformin, in multiple models of disease [186,187]. Intriguingly, metformin alters tumor bed PMN-MDSC accumulation by facilitating an increase in relevant chemokines—primarily CXCL1—signaling [188].

Finally, in order to elicit immune escape, MDSCs must first be recruited to the tumor or inflammatory site. Therefore, antagonism of CXCR2 has been demonstrated to work in combination with traditional chemotherapeutic agents in decreasing cellular senescence and malignancy, primarily through a decrease in MDSC tumor infiltration [189]. Similarly, blockade of interaction of chemokine receptor CCR5, primarily expressed on Mo-MDSC, with its ligands (CCL3, CCL4, and CCL5) significantly improved survival of melanoma-bearing animals [190]. The use of similar agents in combination with drugs that inhibit MDSC function or frequency could be potentially useful in the treatment of pulmonary hypertension.

\section{Conclusions}

The parallels between the pathogenesis of pulmonary hypertension and cancer are extrapolative but have largely been borne out experimentally in multiple animal models and clinical settings. Although best studied in the context of malignancy, MDSCs represent a novel and exciting area of research in the field of pulmonary vascular disease. The role of MDSCs, and PMN-MDSCs in particular, fits neatly into the vast knowledge base previously established on the role of the immune system in the pathogenesis of pulmonary hypertension. While myeloid cells will likely not be a panacea for pulmonary hypertension [191], the major advantage for continued study is the large amount of readily applied translational drugs targeting MDSC-related pathways for use in patients with disease [192].

Author Contributions: A.J.B. conceived of and wrote the manuscript; B.M., T.M.B. and J.D.W. edited and revised the manuscript; L.L.M. conceived of, edited, and revised the manuscript.

Funding: This work was supported by the National Institute of Health (NIH) K08 HL144085 (A.J.B.), P01 AI42288, and R01 DK106191 (to T.M.B.), Gilead Sciences Research Scholars Program in Pulmonary Arterial Hypertension (A.J.B.), Margaret Q. Landenberger Research Foundation (A.J.B.), the American Lung Association (A.J.B.), and the University of Florida Gatorade Trust (A.J.B.).

Conflicts of Interest: The authors declare no conflict of interest.

\section{Abbreviations}

$\begin{array}{ll}\text { CXCR2 } & \text { C-X-C motif chemokine receptor type 2 } \\ \text { IL-8 } & \text { Interleukin 8 } \\ \text { PD-1 } & \text { Programmed cell death protein-1 } \\ \text { PD-L1 } & \text { Programmed death-ligand 1 } \\ \text { Arg1 } & \text { Arginase-1 } \\ \text { iNOS } & \text { Inducible nitric oxide synthase } \\ \text { IDO } & \text { Indoleamine-pyrrole 2,3-dioxygenase }\end{array}$




$\begin{array}{ll}\text { HIF } & \text { Hypoxia-inducible factor } \\ \text { STAT3 } & \text { Signal transducer and activator of transcription 3 } \\ \text { PMN-MDSC } & \text { Polymorphonuclear myeloid-derived suppressor cell } \\ \text { Mo-MDSC } & \text { Monocytic myeloid-derived suppressor cell } \\ \text { DC } & \text { Dendritic cell } \\ \text { M } \phi & \text { Macrophage } \\ \text { Treg } & \text { Regulatory T cell } \\ \mathrm{T}_{\mathrm{H}} 17 & \text { T helper 17 cell } \\ \text { VEGF } & \text { Vascular endothelial growth factor } \\ \text { IL-10 } & \text { Interleukin } 10 \\ \text { IL-6 } & \text { Interleukin } 6 \\ \text { IL-23 } & \text { Interleukin } 23 \\ \text { TGF- } \beta & \text { Transforming growth factor beta }\end{array}$

\section{References}

1. Veglia, F.; Perego, M.; Gabrilovich, D. Myeloid-derived suppressor cells coming of age. Nat. Immunol. 2018, 19, 108-119. [CrossRef] [PubMed]

2. Rieber, N.; Brand, A.; Hector, A.; Graepler-Mainka, U.; Ost, M.; Schafer, I.; Wecker, I.; Neri, D.; Wirth, A.; Mays, L.; et al. Flagellin induces myeloid-derived suppressor cells: Implications for Pseudomonas aeruginosa infection in cystic fibrosis lung disease. J. Immunol. 2013, 190, 1276-1284. [CrossRef] [PubMed]

3. Rieber, N.; Singh, A.; Oz, H.; Carevic, M.; Bouzani, M.; Amich, J.; Ost, M.; Ye, Z.; Ballbach, M.; Schafer, I.; et al. Pathogenic fungi regulate immunity by inducing neutrophilic myeloid-derived suppressor cells. Cell Host Microbe 2015, 17, 507-514. [CrossRef] [PubMed]

4. Du Plessis, N.; Loebenberg, L.; Kriel, M.; von Groote-Bidlingmaier, F.; Ribechini, E.; Loxton, A.G.; van Helden, P.D.; Lutz, M.B.; Walzl, G. Increased frequency of myeloid-derived suppressor cells during active tuberculosis and after recent mycobacterium tuberculosis infection suppresses T.-cell function. Am. J. Respir. Crit. Care Med. 2013, 188, 724-732. [CrossRef] [PubMed]

5. Knaul, J.K.; Jorg, S.; Oberbeck-Mueller, D.; Heinemann, E.; Scheuermann, L.; Brinkmann, V.; Mollenkopf, H.J.; Yeremeev, V.; Kaufmann, S.H.; Dorhoi, A. Lung-residing myeloid-derived suppressors display dual functionality in murine pulmonary tuberculosis. Am. J. Respir. Crit. Care Med. 2014, 190, 1053-1066. [CrossRef] [PubMed]

6. Zhang, C.; Lei, G.S.; Shao, S.; Jung, H.W.; Durant, P.J.; Lee, C.H. Accumulation of myeloid-derived suppressor cells in the lungs during Pneumocystis pneumonia. Infect. Immun. 2012, 80, 3634-3641. [CrossRef] [PubMed]

7. De Santo, C.; Salio, M.; Masri, S.H.; Lee, L.Y.; Dong, T.; Speak, A.O.; Porubsky, S.; Booth, S.; Veerapen, N.; Besra, G.S.; et al. Invariant NKT cells reduce the immunosuppressive activity of influenza A virus-induced myeloid-derived suppressor cells in mice and humans. J. Clin. Investing. 2008, 118, 4036-4048. [CrossRef] [PubMed]

8. Kolahian, S.; Oz, H.H.; Zhou, B.; Griessinger, C.M.; Rieber, N.; Hartl, D. The emerging role of myeloid-derived suppressor cells in lung diseases. Eur. Respir. J. 2016, 47, 967-977. [CrossRef] [PubMed]

9. Yeager, M.E.; Nguyen, C.M.; Belchenko, D.D.; Colvin, K.L.; Takatsuki, S.; Ivy, D.D.; Stenmark, K.R. Circulating myeloid-derived suppressor cells are increased and activated in pulmonary hypertension. Chest 2012, 141, 944-952. [CrossRef] [PubMed]

10. Bryant, A.J.; Shenoy, V.; Fu, C.; Marek, G.; Lorentsen, K.J.; Herzog, E.L.; Brantly, M.L.; Avram, D.; Scott, E.W. Myeloid-derived Suppressor Cells are Necessary for Development of Pulmonary Hypertension. Am. J. Respir. Cell Mol. Biol. 2017, 58, 170-180. [CrossRef] [PubMed]

11. Bronte, V.; Brandau, S.; Chen, S.H.; Colombo, M.P.; Frey, A.B.; Greten, T.F.; Mandruzzato, S.; Murray, P.J.; Ochoa, A.; Ostrand-Rosenberg, S.; et al. Recommendations for myeloid-derived suppressor cell nomenclature and characterization standards. Nat. Commun. 2016, 7, 121-150. [CrossRef] [PubMed]

12. Bian, Z.; Shi, L.; Venkataramani, M.; Abdelaal, A.M.; Culpepper, C.; Kidder, K.; Liang, H.; Zen, K.; Liu, Y. Tumor conditions induce bone marrow expansion of granulocytic, but not monocytic, immunosuppressive leukocytes with increased CXCR2 expression in mice. Eur. J. Immunol. 2018, 48, 532-542. [CrossRef] [PubMed] 
13. Fridlender, Z.G.; Sun, J.; Mishalian, I.; Singhal, S.; Cheng, G.; Kapoor, V.; Horng, W.; Fridlender, G.; Bayuh, R.; Worthen, G.S. Transcriptomic analysis comparing tumor-associated neutrophils with granulocytic myeloid-derived suppressor cells and normal neutrophils. PLoS ONE 2012, 7, e31524. [CrossRef] [PubMed]

14. Donkor, M.K.; Lahue, E.; Hoke, T.A.; Shafer, L.R.; Coskun, U.; Solheim, J.C.; Gulen, D.; Bishay, J.; Talmadge, J.E. Mammary tumor heterogeneity in the expansion of myeloid-derived suppressor cells. Int. Immunopharmacol. 2009, 9, 937-948. [CrossRef] [PubMed]

15. Seguchi, M.; Hirabayashi, N.; Fujii, Y.; Azuno, Y.; Fujita, N.; Takeda, K.; Sato, Y.; Nishimura, M.; Yamada, K.; Oka, Y. Pulmonary hypertension associated with pulmonary occlusive vasculopathy after allogeneic bone marrow transplantation. Transplantation 2000, 69, 177-179. [CrossRef] [PubMed]

16. Pate, A.; Rotz, S.; Warren, M.; Hirsch, R.; Cash, M.; Myers, K.C.; El-Bietar, J.; Nelson, A.; Wallace, G.; Filipovich, A.H.; et al. Pulmonary hypertension associated with bronchiolitis obliterans after hematopoietic stem cell transplantation. Bone Marrow Transplant. 2016, 51, 310-312. [CrossRef] [PubMed]

17. Mattei, D.; Feola, M.; Orzan, F.; Mordini, N.; Rapezzi, D.; Gallamini, A. Reversible dasatinib-induced pulmonary arterial hypertension and right ventricle failure in a previously allografted CML patient. Bone Marrow Transplant. 2009, 43, 967-968. [CrossRef] [PubMed]

18. Binks, M.; Passweg, J.R.; Furst, D.; McSweeney, P.; Sullivan, K.; Besenthal, C.; Finke, J.; Peter, H.H.; van Laar, J.; Breedveld, F.C.; et al. Phase I/II trial of autologous stem cell transplantation in systemic sclerosis: Procedure related mortality and impact on skin disease. Ann. Rheum. Dis. 2001, 60, 577-584. [CrossRef] [PubMed]

19. Vonk, M.C.; Marjanovic, Z.; van den Hoogen, F.H.; Zohar, S.; Schattenberg, A.V.; Fibbe, W.E.; Larghero, J.; Gluckman, E.; Preijers, F.W.; van Dijk, A.P.; et al. Long-term follow-up results after autologous haematopoietic stem cell transplantation for severe systemic sclerosis. Ann. Rheum. Dis. 2008, 67, 98-104. [CrossRef] [PubMed]

20. Sullivan, K.M.; Goldmuntz, E.A.; Keyes-Elstein, L.; McSweeney, P.A.; Pinckney, A.; Welch, B.; Mayes, M.D.; Nash, R.A.; Crofford, L.J.; Eggleston, B.; et al. Myeloablative Autologous Stem-Cell Transplantation for Severe Scleroderma. N. Engl. J. Med. 2018, 378, 35-47. [CrossRef] [PubMed]

21. Loh, Y.; Oyama, Y.; Statkute, L.; Traynor, A.; Satkus, J.; Quigley, K.; Yaung, K.; Barr, W.; Bucha, J.; Gheorghiade, M.; et al. Autologous hematopoietic stem cell transplantation in systemic lupus erythematosus patients with cardiac dysfunction: Feasibility and reversibility of ventricular and valvular dysfunction with transplant-induced remission. Bone Marrow Transplant 2007, 40, 47-53. [CrossRef] [PubMed]

22. Traynor, A.E.; Corbridge, T.C.; Eagan, A.E.; Barr, W.G.; Liu, Q.; Oyama, Y.; Burt, R.K. Prevalence and reversibility of pulmonary dysfunction in refractory systemic lupus: Improvement correlates with disease remission following hematopoietic stem cell transplantation. Chest 2005, 127, 1680-1689. [CrossRef] [PubMed]

23. Pittman, C.; Hsieh, M.M.; Coles, W.; Tisdale, J.F.; Weir, N.A.; Fitzhugh, C.D. Reversal of pre-capillary pulmonary hypertension in a patient with sickle cell anemia who underwent haploidentical peripheral blood stem cell transplantation. Bone Marrow Transplant 2017, 52, 641-642. [CrossRef] [PubMed]

24. Zhao, Y.D.; Courtman, D.W.; Deng, Y.; Kugathasan, L.; Zhang, Q.; Stewart, D.J. Rescue of monocrotaline-induced pulmonary arterial hypertension using bone marrow-derived endothelial-like progenitor cells: Efficacy of combined cell and eNOS gene therapy in established disease. Circ. Res. 2005, 96, 442-450. [CrossRef] [PubMed]

25. Kanki-Horimoto, S.; Horimoto, H.; Mieno, S.; Kishida, K.; Watanabe, F.; Furuya, E.; Katsumata, T. Implantation of mesenchymal stem cells overexpressing endothelial nitric oxide synthase improves right ventricular impairments caused by pulmonary hypertension. Circulation 2006, 114, I181-1185. [CrossRef] [PubMed]

26. Satoh, K.; Kagaya, Y.; Nakano, M.; Ito, Y.; Ohta, J.; Tada, H.; Karibe, A.; Minegishi, N.; Suzuki, N.; Yamamoto, M.; et al. Important role of endogenous erythropoietin system in recruitment of endothelial progenitor cells in hypoxia-induced pulmonary hypertension in mice. Circulation 2006, 113, 1442-1450. [CrossRef] [PubMed]

27. Raoul, W.; Wagner-Ballon, O.; Saber, G.; Hulin, A.; Marcos, E.; Giraudier, S.; Vainchenker, W.; Adnot, S.; Eddahibi, S.; Maitre, B. Effects of bone marrow-derived cells on monocrotaline- and hypoxia-induced pulmonary hypertension in mice. Respir. Res. 2007, 8, 8-10. [CrossRef] [PubMed] 
28. Sahara, M.; Sata, M.; Morita, T.; Nakamura, K.; Hirata, Y.; Nagai, R. Diverse contribution of bone marrow-derived cells to vascular remodeling associated with pulmonary arterial hypertension and arterial neointimal formation. Circulation 2007, 115, 509-517. [CrossRef] [PubMed]

29. Aliotta, J.M.; Keaney, P.J.; Warburton, R.R.; DelTatto, M.; Dooner, M.S.; Passero, M.A.; Quesenberry, P.J.; Klinger, J.R. Marrow cell infusion attenuates vascular remodeling in a murine model of monocrotaline-induced pulmonary hypertension. Stem Cells Dev. 2009, 18, 773-782. [CrossRef] [PubMed]

30. Umar, S.; de Visser, Y.P.; Steendijk, P.; Schutte, C.I.; Laghmani el, H.; Wagenaar, G.T.; Bax, W.H.; Mantikou, E.; Pijnappels, D.A.; Atsma, D.E.; et al. Allogenic stem cell therapy improves right ventricular function by improving lung pathology in rats with pulmonary hypertension. Am. J. Physiol. Heart Circ. Physiol. 2009, 297, H1606-H1616. [CrossRef] [PubMed]

31. Luan, Y.; Zhang, Z.H.; Wei, D.E.; Lu, Y.; Wang, Y.B. Effects of autologous bone marrow mononuclear cells implantation in canine model of pulmonary hypertension. Circ. J. 2012, 76, 977-985. [CrossRef] [PubMed]

32. Yan, L.; Chen, X.; Talati, M.; Nunley, B.W.; Gladson, S.; Blackwell, T.; Cogan, J.; Austin, E.; Wheeler, F.; Loyd, J.; et al. Bone Marrow-derived Cells Contribute to the Pathogenesis of Pulmonary Arterial Hypertension. Am. J. Respir. Crit. Care Med. 2016, 193, 898-909. [CrossRef] [PubMed]

33. Asosingh, K.; Wanner, N.; Weiss, K.; Queisser, K.; Gebreab, L.; Kassa, B.; Stuehr, E.; Graham, B.; Erzurum, S. Bone marrow transplantation prevents right ventricle disease in the caveolin-1-deficient mouse model of pulmonary hypertension. Blood. Adv. 2017, 1, 526-534. [CrossRef] [PubMed]

34. Dingli, D.; Utz, J.P.; Krowka, M.J.; Oberg, A.L.; Tefferi, A. Unexplained pulmonary hypertension in chronic myeloproliferative disorders. Chest 2001, 120, 801-808. [CrossRef] [PubMed]

35. Garypidou, V.; Vakalopoulou, S.; Dimitriadis, D.; Tziomalos, K.; Sfikas, G.; Perifanis, V. Incidence of pulmonary hypertension in patients with chronic myeloproliferative disorders. Haematologica 2004, 89, 245-246. [PubMed]

36. Garcia-Manero, G.; Schuster, S.J.; Patrick, H.; Martinez, J. Pulmonary hypertension in patients with myelofibrosis secondary to myeloproliferative diseases. Am. J. Hematol. 1999, 60, 130-135. [CrossRef]

37. Roach, E.C.; Park, M.M.; Tang, W.H.; Thomas, J.D.; Asosingh, K.; Kalaycio, M.; Erzurum, S.C.; Farha, S. Impaired right ventricular-pulmonary vascular function in myeloproliferative neoplasms. J. Heart Lung Transplant 2015, 34, 390-394. [CrossRef] [PubMed]

38. Mattar, M.M.; Morad, M.A.; El Husseiny, N.M.; Ali, N.H.; El Demerdash, D.M. Correlation between JAK2 allele burden and pulmonary arterial hypertension and hematological parameters in Philadelphia negative JAK2 positive myeloproliferative neoplasms. An Egyptian experience. Ann. Hematol. 2016, 95, 1611-1616. [CrossRef] [PubMed]

39. Popat, U.; Frost, A.; Liu, E.; Guan, Y.; Durette, A.; Reddy, V.; Prchal, J.T. High levels of circulating CD34 cells, dacrocytes, clonal hematopoiesis, and JAK2 mutation differentiate myelofibrosis with myeloid metaplasia from secondary myelofibrosis associated with pulmonary hypertension. Blood 2006, 107, 3486-3488. [CrossRef] [PubMed]

40. Faiz, S.A.; Iliescu, C.; Lopez-Mattei, J.; Patel, B.; Bashoura, L.; Popat, U. Resolution of myelofibrosis-associated pulmonary arterial hypertension following allogeneic hematopoietic stem cell transplantation. Pulm. Circ. 2016, 6, 611-613. [CrossRef] [PubMed]

41. Mathew, R.; Huang, J.; Wu, J.M.; Fallon, J.T.; Gewitz, M.H. Hematological disorders and pulmonary hypertension. World J. Cardiol. 2016, 8, 703-718. [CrossRef] [PubMed]

42. Adir, Y.; Elia, D.; Harari, S. Pulmonary hypertension in patients with chronic myeloproliferative disorders. Eur. Respir. Rev. 2015, 24, 400-410. [CrossRef] [PubMed]

43. Adir, Y.; Humbert, M. Pulmonary hypertension in patients with chronic myeloproliferative disorders. Eur. Respir. J. 2010, 35, 1396-1406. [CrossRef] [PubMed]

44. Raychaudhuri, B.; Bonfield, T.L.; Malur, A.; Hague, K.; Kavuru, M.S.; Arroliga, A.C.; Thomassen, M.J. Circulating monocytes from patients with primary pulmonary hypertension are hyporesponsive. Clin. Immunol. 2002, 104, 191-198. [CrossRef] [PubMed]

45. Rose, F.; Hattar, K.; Gakisch, S.; Grimminger, F.; Olschewski, H.; Seeger, W.; Tschuschner, A.; Schermuly, R.T.; Weissmann, N.; Hanze, J.; et al. Increased neutrophil mediator release in patients with pulmonary hypertension-suppression by inhaled iloprost. Thromb. Haemost. 2003, 90, 1141-1149. [CrossRef] [PubMed] 
46. Asosingh, K.; Aldred, M.A.; Vasanji, A.; Drazba, J.; Sharp, J.; Farver, C.; Comhair, S.A.; Xu, W.; Licina, L.; Huang, L.; et al. Circulating angiogenic precursors in idiopathic pulmonary arterial hypertension. Am. J. Pathol. 2008, 172, 615-627. [CrossRef] [PubMed]

47. Farha, S.; Asosingh, K.; Xu, W.; Sharp, J.; George, D.; Comhair, S.; Park, M.; Tang, W.H.; Loyd, J.E.; Theil, K.; et al. Hypoxia-inducible factors in human pulmonary arterial hypertension: A link to the intrinsic myeloid abnormalities. Blood 2011, 117, 3485-3493. [CrossRef] [PubMed]

48. Asosingh, K.; Farha, S.; Lichtin, A.; Graham, B.; George, D.; Aldred, M.; Hazen, S.L.; Loyd, J.; Tuder, R.; Erzurum, S.C. Pulmonary vascular disease in mice xenografted with human BM progenitors from patients with pulmonary arterial hypertension. Blood 2012, 120, 1218-1227. [CrossRef] [PubMed]

49. Frid, M.G.; Brunetti, J.A.; Burke, D.L.; Carpenter, T.C.; Davie, N.J.; Reeves, J.T.; Roedersheimer, M.T.; van Rooijen, N.; Stenmark, K.R. Hypoxia-induced pulmonary vascular remodeling requires recruitment of circulating mesenchymal precursors of a monocyte/macrophage lineage. Am. J. Pathol. 2006, 168, 659-669. [CrossRef] [PubMed]

50. Rabinovitch, M.; Guignabert, C.; Humbert, M.; Nicolls, M.R. Inflammation and immunity in the pathogenesis of pulmonary arterial hypertension. Circ. Res. 2014, 115, 165-175. [CrossRef] [PubMed]

51. Tian, W.; Jiang, X.; Tamosiuniene, R.; Sung, Y.K.; Qian, J.; Dhillon, G.; Gera, L.; Farkas, L.; Rabinovitch, M.; Zamanian, R.T.; et al. Blocking macrophage leukotriene b4 prevents endothelial injury and reverses pulmonary hypertension. Sci. Transl. Med. 2013, 5, 117-200. [CrossRef] [PubMed]

52. Sawada, H.; Saito, T.; Nickel, N.P.; Alastalo, T.P.; Glotzbach, J.P.; Chan, R.; Haghighat, L.; Fuchs, G.; Januszyk, M.; Cao, A.; et al. Reduced BMPR2 expression induces GM-CSF translation and macrophage recruitment in humans and mice to exacerbate pulmonary hypertension. J. Exp. Med. 2014, 211, $263-280$. [CrossRef] [PubMed]

53. Hashimoto-Kataoka, T.; Hosen, N.; Sonobe, T.; Arita, Y.; Yasui, T.; Masaki, T.; Minami, M.; Inagaki, T.; Miyagawa, S.; Sawa, Y.; et al. Interleukin-6/interleukin-21 signaling axis is critical in the pathogenesis of pulmonary arterial hypertension. Proc. Natl. Acad. Sci. USA 2015, 112, E2677-E2686. [CrossRef] [PubMed]

54. Kumar, R.; Mickael, C.; Chabon, J.; Gebreab, L.; Rutebemberwa, A.; Garcia, A.R.; Koyanagi, D.E.; Sanders, L.; Gandjeva, A.; Kearns, M.T.; et al. The Causal Role of IL-4 and IL-13 in Schistosoma mansoni Pulmonary Hypertension. Am. J. Respir. Crit. Care. Med. 2015, 192, 998-1008. [CrossRef] [PubMed]

55. Yoshida, H.; Kitaichi, T.; Urata, M.; Kurobe, H.; Kanbara, T.; Motoki, T.; Kitagawa, T. Syngeneic bone marrow mononuclear cells improve pulmonary arterial hypertension through vascular endothelial growth factor upregulation. Ann. Thorac. Surg. 2009, 88, 418-424. [CrossRef] [PubMed]

56. Huang, W.C.; Ke, M.W.; Cheng, C.C.; Chiou, S.H.; Wann, S.R.; Shu, C.W.; Chiou, K.R.; Tseng, C.J.; Pan, H.W.; Mar, G.Y.; et al. Therapeutic Benefits of Induced Pluripotent Stem Cells in Monocrotaline-Induced Pulmonary Arterial Hypertension. PLoS ONE 2016, 11, e0142476. [CrossRef] [PubMed]

57. Talati, M.; West, J.; Zaynagetdinov, R.; Hong, C.C.; Han, W.; Blackwell, T.; Robinson, L.; Blackwell, T.S.; Lane, K. BMP pathway regulation of and by macrophages. PLoS ONE 2014, 9, e94119. [CrossRef] [PubMed]

58. Yu, Y.R.; Mao, L.; Piantadosi, C.A.; Gunn, M.D. CCR2 deficiency, dysregulation of Notch signaling, and spontaneous pulmonary arterial hypertension. Am. J Respir. Cell Mol. Biol. 2013, 48, 647-654. [CrossRef] [PubMed]

59. Harbaum, L.; Baaske, K.M.; Simon, M.; Oqueka, T.; Sinning, C.; Glatzel, A.; Luneburg, N.; Sydow, K.; Bokemeyer, C.; Klose, H. Exploratory analysis of the neutrophil to lymphocyte ratio in patients with pulmonary arterial hypertension. BMC. Pulm. Med. 2017, 17, 72-78. [CrossRef] [PubMed]

60. Aldabbous, L.; Abdul-Salam, V.; McKinnon, T.; Duluc, L.; Pepke-Zaba, J.; Southwood, M.; Ainscough, A.J.; Hadinnapola, C.; Wilkins, M.R.; Toshner, M.; et al. Neutrophil Extracellular Traps Promote Angiogenesis: Evidence from Vascular Pathology in Pulmonary Hypertension. Arterioscler. Thromb. Vasc. Biol. 2016, 36, 2078-2087. [CrossRef] [PubMed]

61. Burger, R.; Bryan, A.C. Pulmonary hypertension after postlavage lung injury in rabbits: Possible role of polymorphonuclear leukocytes. J. Appl. Physiol. 1991, 71, 1990-1995. [CrossRef] [PubMed]

62. Perkett, E.A.; Brigham, K.L.; Meyrick, B. Granulocyte depletion attenuates sustained pulmonary hypertension and increased pulmonary vasoreactivity caused by continuous air embolization in sheep. Am. Rev. Respir. Dis. 1990, 141, 456-465. [CrossRef] [PubMed] 
63. Burton, V.J.; Ciuclan, L.I.; Holmes, A.M.; Rodman, D.M.; Walker, C.; Budd, D.C. Bone morphogenetic protein receptor II regulates pulmonary artery endothelial cell barrier function. Blood 2011, 117, 333-341. [CrossRef] [PubMed]

64. Burton, V.J.; Holmes, A.M.; Ciuclan, L.I.; Robinson, A.; Roger, J.S.; Jarai, G.; Pearce, A.C.; Budd, D.C. Attenuation of leukocyte recruitment via CXCR1/2 inhibition stops the progression of PAH in mice with genetic ablation of endothelial BMPR-II. Blood 2011, 118, 4750-4758. [CrossRef] [PubMed]

65. Marsh, L.M.; Jandl, K.; Grunig, G.; Foris, V.; Bashir, M.; Ghanim, B.; Klepetko, W.; Olschewski, H.; Olschewski, A.; Kwapiszewska, G. The inflammatory cell landscape in the lungs of patients with idiopathic pulmonary arterial hypertension. Eur. Respir. J. 2018, 51, 36-40. [CrossRef] [PubMed]

66. Launay, J.M.; Herve, P.; Callebert, J.; Mallat, Z.; Collet, C.; Doly, S.; Belmer, A.; Diaz, S.L.; Hatia, S.; Cote, F; et al. Serotonin 5-HT2B receptors are required for bone-marrow contribution to pulmonary arterial hypertension. Blood 2012, 119, 1772-1780. [CrossRef] [PubMed]

67. Gerasimovskaya, E.; Kratzer, A.; Sidiakova, A.; Salys, J.; Zamora, M.; Taraseviciene-Stewart, L. Interplay of macrophages and T cells in the lung vasculature. Am. J. Physiol. Lung Cell Mol. Physiol. 2012, 302, L1014-L1022. [CrossRef] [PubMed]

68. Maston, L.D.; Jones, D.T.; Giermakowska, W.; Howard, T.A.; Cannon, J.L.; Wang, W.; Wei, Y.; Xuan, W.; Resta, T.C.; Gonzalez Bosc, L.V. Central role of T helper 17 cells in chronic hypoxia-induced pulmonary hypertension. Am. J. Physiol. Lung Cell Mol. Physiol. 2017, 312, L609-L624. [CrossRef] [PubMed]

69. Weng, M.; Baron, D.M.; Bloch, K.D.; Luster, A.D.; Lee, J.J.; Medoff, B.D. Eosinophils are necessary for pulmonary arterial remodeling in a mouse model of eosinophilic inflammation-induced pulmonary hypertension. Am. J. Physiol. Lung Cell Mol. Physiol. 2011, 301, L927-L936. [CrossRef] [PubMed]

70. Stenmark, K.R.; Frid, M.G.; Yeager, M.E. Fibrocytes: Potential new therapeutic targets for pulmonary hypertension? Eur. Respir. J. 2010, 36, 1232-1235. [CrossRef] [PubMed]

71. Ormiston, M.L.; Deng, Y.; Stewart, D.J.; Courtman, D.W. Innate immunity in the therapeutic actions of endothelial progenitor cells in pulmonary hypertension. Am. J. Respir. Cell Mol. Biol. 2010, 43, 546-554. [CrossRef] [PubMed]

72. Fadini, G.P.; Avogaro, A.; Ferraccioli, G.; Agostini, C. Endothelial progenitors in pulmonary hypertension: New pathophysiology and therapeutic implications. Eur. Respir. J. 2010, 35, 418-425. [CrossRef] [PubMed]

73. Sata, M. Role of circulating vascular progenitors in angiogenesis, vascular healing, and pulmonary hypertension: Lessons from animal models. Arterioscler. Thromb. Vasc. Biol. 2006, 26, 1008-1014. [CrossRef] [PubMed]

74. Maxova, H.; Herget, J.; Vizek, M. Lung mast cells and hypoxic pulmonary hypertension. Physiol. Res. 2012, 61, 1-11. [PubMed]

75. Fu, J.; Chen, Y.F.; Zhao, X.; Creighton, J.R.; Guo, Y.; Hage, F.G.; Oparil, S.; Xing, D.D. Targeted delivery of pulmonary arterial endothelial cells overexpressing interleukin-8 receptors attenuates monocrotaline-induced pulmonary vascular remodeling. Arterioscler. Thromb. Vasc. Biol. 2014, 34, 1539-1547. [CrossRef] [PubMed]

76. Katoh, H.; Wang, D.; Daikoku, T.; Sun, H.; Dey, S.K.; Dubois, R.N. CXCR2-expressing myeloid-derived suppressor cells are essential to promote colitis-associated tumorigenesis. Cancer Cell 2013, 24, 631-644. [CrossRef] [PubMed]

77. Steele, C.W.; Karim, S.A.; Leach, J.D.G.; Bailey, P.; Upstill-Goddard, R.; Rishi, L.; Foth, M.; Bryson, S.; McDaid, K.; Wilson, Z.; et al. CXCR2 Inhibition Profoundly Suppresses Metastases and Augments Immunotherapy in Pancreatic Ductal Adenocarcinoma. Cancer Cell. 2016, 29, 832-845. [CrossRef] [PubMed]

78. Zhang, H.; Ye, Y.L.; Li, M.X.; Ye, S.B.; Huang, W.R.; Cai, T.T.; He, J.; Peng, J.Y.; Duan, T.H.; Cui, J.; et al. CXCL2/MIF-CXCR2 signaling promotes the recruitment of myeloid-derived suppressor cells and is correlated with prognosis in bladder cancer. Oncogene 2017, 36, 2095-2104. [CrossRef] [PubMed]

79. Amsellem, V.; Abid, S.; Poupel, L.; Parpaleix, A.; Rodero, M.; Gary-Bobo, G.; Latiri, M.; Dubois-Rande, J.L.; Lipskaia, L.; Combadiere, C.; et al. Roles for the CX3CL1/CX3CR1 and CCL2/CCR2 Chemokine Systems in Hypoxic Pulmonary Hypertension. Am. J. Respir. Cell Mol. Biol. 2017, 56, 597-608. [CrossRef] [PubMed]

80. Florentin, J.; Coppin, E.; Vasamsetti, S.B.; Zhao, J.; Tai, Y.Y.; Tang, Y.; Zhang, Y.; Watson, A.; Sembrat, J.; Rojas, M.; et al. Inflammatory Macrophage Expansion in Pulmonary Hypertension Depends upon Mobilization of Blood-Borne Monocytes. J. Immunol. 2018, 200, 3612-3625. [CrossRef] [PubMed] 
81. Kao, C.C.; Wedes, S.H.; Hsu, J.W.; Bohren, K.M.; Comhair, S.A.; Jahoor, F.; Erzurum, S.C. Arginine metabolic endotypes in pulmonary arterial hypertension. Pulm. Circ. 2015, 5, 124-134. [CrossRef] [PubMed]

82. Cowburn, A.S.; Crosby, A.; Macias, D.; Branco, C.; Colaco, R.D.; Southwood, M.; Toshner, M.; Crotty Alexander, L.E.; Morrell, N.W.; Chilvers, E.R.; et al. HIF2alpha-arginase axis is essential for the development of pulmonary hypertension. Proc. Natl. Acad. Sci. USA 2016, 113, 8801-8806. [CrossRef] [PubMed]

83. Trittmann, J.K.; Jin, Y.; Chicoine, L.G.; Liu, Y.; Chen, B.; Nelin, L.D. An arginase-1 SNP that protects against the development of pulmonary hypertension in bronchopulmonary dysplasia enhances NO-mediated apoptosis in lymphocytes. Physiol. Rep. 2016, 4, 801-806. [CrossRef] [PubMed]

84. Jung, C.; Grun, K.; Betge, S.; Pernow, J.; Kelm, M.; Muessig, J.; Masyuk, M.; Kuethe, F.; Ndongson-Dongmo, B.; Bauer, R.; et al. Arginase Inhibition Reverses Monocrotaline-Induced Pulmonary Hypertension. Int. J. Mol. Sci. 2017, 18, 1609. [CrossRef] [PubMed]

85. Bian, Z.; Abdelaal, A.M.; Shi, L.; Liang, H.; Xiong, L.; Kidder, K.; Venkataramani, M.; Culpepper, C.; Zen, K.; Liu, Y. Arginase-1 is neither constitutively expressed in nor required for myeloid-derived suppressor cell-mediated inhibition of T.-cell proliferation. Eur. J. Immunol. 2018, 48, 1046-1058. [CrossRef] [PubMed]

86. Azzaoui, I.; Uhel, F.; Rossille, D.; Pangault, C.; Dulong, J.; Le Priol, J.; Lamy, T.; Houot, R.; Le Gouill, S.; Cartron, G.; et al. T-cell defect in diffuse large B-cell lymphomas involves expansion of myeloid-derived suppressor cells. Blood 2016, 128, 1081-1092. [CrossRef] [PubMed]

87. Zhang, J.; Xu, X.; Shi, M.; Chen, Y.; Yu, D.; Zhao, C.; Gu, Y.; Yang, B.; Guo, S.; Ding, G.; et al. CD13(hi) Neutrophil-like myeloid-derived suppressor cells exert immune suppression through Arginase 1 expression in pancreatic ductal adenocarcinoma. Oncoimmunology 2017, 6, e1258504. [CrossRef] [PubMed]

88. Kostlin, N.; Vogelmann, M.; Spring, B.; Schwarz, J.; Feucht, J.; Hartel, C.; Orlikowsky, T.W.; Poets, C.F.; Gille, C. Granulocytic myeloid-derived suppressor cells from human cord blood modulate T-helper cell response towards an anti-inflammatory phenotype. Immunology 2017, 152, 89-101. [CrossRef] [PubMed]

89. Zuckerbraun, B.S.; George, P.; Gladwin, M.T. Nitrite in pulmonary arterial hypertension: Therapeutic avenues in the setting of dysregulated arginine/nitric oxide synthase signalling. Cardiovasc. Res. 2011, 89, 542-552. [CrossRef] [PubMed]

90. Ogoshi, T.; Tsutsui, M.; Kido, T.; Sakanashi, M.; Naito, K.; Oda, K.; Ishimoto, H.; Yamada, S.; Wang, K.Y.; Toyohira, Y.; et al. Protective Role of Myelocytic Nitric Oxide Synthases Against Hypoxic Pulmonary Hypertension in Mice. Am. J. Respir. Crit. Care Med. 2018, 3, 52-56. [CrossRef] [PubMed]

91. Seimetz, M.; Parajuli, N.; Pichl, A.; Veit, F.; Kwapiszewska, G.; Weisel, F.C.; Milger, K.; Egemnazarov, B.; Turowska, A.; Fuchs, B.; et al. Inducible NOS inhibition reverses tobacco-smoke-induced emphysema and pulmonary hypertension in mice. Cell 2011, 147, 293-305. [CrossRef] [PubMed]

92. Haverkamp, J.M.; Crist, S.A.; Elzey, B.D.; Cimen, C.; Ratliff, T.L. In vivo suppressive function of myeloid-derived suppressor cells is limited to the inflammatory site. Eur. J. Immunol. 2011, 41, 749-759. [CrossRef] [PubMed]

93. Jayaraman, P.; Parikh, F.; Lopez-Rivera, E.; Hailemichael, Y.; Clark, A.; Ma, G.; Cannan, D.; Ramacher, M.; Kato, M.; Overwijk, W.W.; et al. Tumor-expressed inducible nitric oxide synthase controls induction of functional myeloid-derived suppressor cells through modulation of vascular endothelial growth factor release. J. Immunol. 2012, 188, 5365-5376. [CrossRef] [PubMed]

94. Hampl, V.; Bibova, J.; Banasova, A.; Uhlik, J.; Mikova, D.; Hnilickova, O.; Lachmanova, V.; Herget, J. Pulmonary vascular iNOS induction participates in the onset of chronic hypoxic pulmonary hypertension. Am. J. Physiol. Lung Cell Mol. Physiol. 2006, 290, L11-L20. [CrossRef] [PubMed]

95. Mondanelli, G.; Bianchi, R.; Pallotta, M.T.; Orabona, C.; Albini, E.; Iacono, A.; Belladonna, M.L.; Vacca, C.; Fallarino, F.; Macchiarulo, A.; et al. A Relay Pathway between Arginine and Tryptophan Metabolism Confers Immunosuppressive Properties on Dendritic Cells. Immunity 2017, 46, 233-244. [CrossRef] [PubMed]

96. Xiao, Y.; Christou, H.; Liu, L.; Visner, G.; Mitsialis, S.A.; Kourembanas, S.; Liu, H. Endothelial indoleamine 2,3-dioxygenase protects against development of pulmonary hypertension. Am. J. Respir. Crit. Care Med. 2013, 188, 482-491. [CrossRef] [PubMed]

97. Lewis, G.D.; Ngo, D.; Hemnes, A.R.; Farrell, L.; Domos, C.; Pappagianopoulos, P.P.; Dhakal, B.P.; Souza, A.; Shi, X.; Pugh, M.E.; et al. Metabolic Profiling of Right Ventricular-Pulmonary Vascular Function Reveals Circulating Biomarkers of Pulmonary Hypertension. J. Am. Coll. Cardiol. 2016, 67, 174-189. [CrossRef] [PubMed] 
98. Nagy, B.M.; Nagaraj, C.; Meinitzer, A.; Sharma, N.; Papp, R.; Foris, V.; Ghanim, B.; Kwapiszewska, G.; Kovacs, G.; Klepetko, W.; et al. Importance of kynurenine in pulmonary hypertension. Am. J. Physiol. Lung Cell Mol. Physiol. 2017, 313, L741-L751. [CrossRef] [PubMed]

99. Yu, J.; Wang, Y.; Yan, F.; Zhang, P.; Li, H.; Zhao, H.; Yan, C.; Yan, F.; Ren, X. Noncanonical NF-kappaB activation mediates STAT3-stimulated IDO upregulation in myeloid-derived suppressor cells in breast cancer. J. Immunol. 2014, 193, 2574-2586. [CrossRef] [PubMed]

100. Yu, J.; Du, W.; Yan, F.; Wang, Y.; Li, H.; Cao, S.; Yu, W.; Shen, C.; Liu, J.; Ren, X. Myeloid-derived suppressor cells suppress antitumor immune responses through IDO expression and correlate with lymph node metastasis in patients with breast cancer. J. Immunol. 2013, 190, 3783-3797. [CrossRef] [PubMed]

101. Jitschin, R.; Braun, M.; Buttner, M.; Dettmer-Wilde, K.; Bricks, J.; Berger, J.; Eckart, M.J.; Krause, S.W.; Oefner, P.J.; Le Blanc, K.; et al. CLL-cells induce IDOhi CD14+HLA-DRlo myeloid-derived suppressor cells that inhibit T-cell responses and promote TRegs. Blood 2014, 124, 750-760. [CrossRef] [PubMed]

102. Zoso, A.; Mazza, E.M.; Bicciato, S.; Mandruzzato, S.; Bronte, V.; Serafini, P.; Inverardi, L. Human fibrocytic myeloid-derived suppressor cells express IDO and promote tolerance via Treg-cell expansion. Eur. J. Immunol. 2014, 44, 3307-3319. [CrossRef] [PubMed]

103. Holmgaard, R.B.; Zamarin, D.; Li, Y.; Gasmi, B.; Munn, D.H.; Allison, J.P.; Merghoub, T.; Wolchok, J.D. Tumor-Expressed IDO Recruits and Activates MDSCs in a Treg-Dependent Manner. Cell. Rep. 2015, 13, 412-424. [CrossRef] [PubMed]

104. Paulin, R.; Courboulin, A.; Meloche, J.; Mainguy, V.; Dumas de la Roque, E.; Saksouk, N.; Cote, J.; Provencher, S.; Sussman, M.A.; Bonnet, S. Signal transducers and activators of transcription-3/pim1 axis plays a critical role in the pathogenesis of human pulmonary arterial hypertension. Circulation 2011, 123, 1205-1215. [CrossRef] [PubMed]

105. Paulin, R.; Meloche, J.; Jacob, M.H.; Bisserier, M.; Courboulin, A.; Bonnet, S. Dehydroepiandrosterone inhibits the Src/STAT3 constitutive activation in pulmonary arterial hypertension. Am. J. Physiol. Heart Circ. Physiol. 2011, 301, H1798-H1809. [CrossRef] [PubMed]

106. Dong, G.; Si, C.; Zhang, Q.; Yan, F.; Li, C.; Zhang, H.; Ma, Q.; Dai, J.; Li, Z.; Shi, H.; et al. Autophagy regulates accumulation and functional activity of granulocytic myeloid-derived suppressor cells via STAT3 signaling in endotoxin shock. Biochim. Biophys. Acta 2017, 1863, 2796-2807. [CrossRef] [PubMed]

107. Paulin, R.; Meloche, J.; Bonnet, S. STAT3 signaling in pulmonary arterial hypertension. Jakstat 2012, 1, 223-233. [CrossRef] [PubMed]

108. Wu, L.; Du, H.; Li, Y.; Qu, P.; Yan, C. Signal transducer and activator of transcription 3 (Stat3C) promotes myeloid-derived suppressor cell expansion and immune suppression during lung tumorigenesis. Am. J. Pathol. 2011, 179, 2131-2141. [CrossRef] [PubMed]

109. Yu, A.Y.; Shimoda, L.A.; Iyer, N.V.; Huso, D.L.; Sun, X.; McWilliams, R.; Beaty, T.; Sham, J.S.; Wiener, C.M.; Sylvester, J.T.; et al. Impaired physiological responses to chronic hypoxia in mice partially deficient for hypoxia-inducible factor 1alpha. J. Clin. Investig. 1999, 103, 691-696. [CrossRef] [PubMed]

110. Brusselmans, K.; Compernolle, V.; Tjwa, M.; Wiesener, M.S.; Maxwell, P.H.; Collen, D.; Carmeliet, P. Heterozygous deficiency of hypoxia-inducible factor-2alpha protects mice against pulmonary hypertension and right ventricular dysfunction during prolonged hypoxia. J. Clin. Investig. 2003, 111, 1519-1527. [CrossRef] [PubMed]

111. Sheikh, A.Q.; Saddouk, F.Z.; Ntokou, A.; Mazurek, R.; Greif, D.M. Cell Autonomous and Non-cell Autonomous Regulation of SMC Progenitors in Pulmonary Hypertension. Cell Rep. 2018, 23, 1152-1165. [CrossRef] [PubMed]

112. Chaturvedi, P.; Gilkes, D.M.; Takano, N.; Semenza, G.L. Hypoxia-inducible factor-dependent signaling between triple-negative breast cancer cells and mesenchymal stem cells promotes macrophage recruitment. Proc. Natl. Acad. Sci. USA 2014, 111, E2120-9. [CrossRef] [PubMed]

113. Corzo, C.A.; Condamine, T.; Lu, L.; Cotter, M.J.; Youn, J.I.; Cheng, P.; Cho, H.I.; Celis, E.; Quiceno, D.G.; Padhya, T; et al. HIF-1alpha regulates function and differentiation of myeloid-derived suppressor cells in the tumor microenvironment. J. Exp. Med. 2010, 207, 2439-2453. [CrossRef] [PubMed]

114. Kumar, V.; Gabrilovich, D.I. Hypoxia-inducible factors in regulation of immune responses in tumour microenvironment. Immunology 2014, 143, 512-519. [CrossRef] [PubMed] 
115. Cubillos-Zapata, C.; Avendano-Ortiz, J.; Hernandez-Jimenez, E.; Toledano, V.; Casas-Martin, J.; Varela-Serrano, A.; Torres, M.; Almendros, I.; Casitas, R.; Fernandez-Navarro, I.; et al. Hypoxia-induced PD-L1/PD-1 crosstalk impairs T-cell function in sleep apnoea. Eur. Respir. J. 2017, 50, 34-36. [CrossRef] [PubMed]

116. Noman, M.Z.; Desantis, G.; Janji, B.; Hasmim, M.; Karray, S.; Dessen, P.; Bronte, V.; Chouaib, S. PD-L1 is a novel direct target of HIF-1alpha, and its blockade under hypoxia enhanced MDSC-mediated T. cell activation. J. Exp. Med. 2014, 211, 781-790. [CrossRef] [PubMed]

117. Savai, R.; Pullamsetti, S.S.; Kolbe, J.; Bieniek, E.; Voswinckel, R.; Fink, L.; Scheed, A.; Ritter, C.; Dahal, B.K.; Vater, A.; et al. Immune and inflammatory cell involvement in the pathology of idiopathic pulmonary arterial hypertension. Am. J. Respir. Crit. Care Med. 2012, 186, 897-908. [CrossRef] [PubMed]

118. Perros, F.; Dorfmuller, P.; Souza, R.; Durand-Gasselin, I.; Mussot, S.; Mazmanian, M.; Herve, P.; Emilie, D.; Simonneau, G.; Humbert, M. Dendritic cell recruitment in lesions of human and experimental pulmonary hypertension. Eur. Respir. J. 2007, 29, 462-468. [CrossRef] [PubMed]

119. Burke, D.L.; Frid, M.G.; Kunrath, C.L.; Karoor, V.; Anwar, A.; Wagner, B.D.; Strassheim, D.; Stenmark, K.R. Sustained hypoxia promotes the development of a pulmonary artery-specific chronic inflammatory microenvironment. Am. J. Physiol. Lung Cell Mol. Physiol. 2009, 297, L238-L250. [CrossRef] [PubMed]

120. Wang, W.; Yan, H.; Zhu, W.; Cui, Y.; Chen, J.; Wang, X.; Li, S.; Zhu, J. Impairment of monocyte-derived dendritic cells in idiopathic pulmonary arterial hypertension. J. Clin. Immunol. 2009, 29, 705-713. [CrossRef] [PubMed]

121. Sendo, S.; Saegusa, J.; Okano, T.; Takahashi, S.; Akashi, K.; Morinobu, A. CD11b+Gr-1(dim) Tolerogenic Dendritic Cell-Like Cells Are Expanded in Interstitial Lung Disease in SKG Mice. Arthritis Rheumatol. 2017, 69, 2314-2327. [CrossRef] [PubMed]

122. Albeituni, S.H.; Ding, C.; Liu, M.; Hu, X.; Luo, F.; Kloecker, G.; Bousamra, M., 2nd; Zhang, H.G.; Yan, J. Yeast-Derived Particulate beta-Glucan Treatment Subverts the Suppression of Myeloid-Derived Suppressor Cells (MDSC) by Inducing Polymorphonuclear MDSC Apoptosis and Monocytic MDSC Differentiation to APC in Cancer. J. Immunol. 2016, 196, 2167-2180. [CrossRef] [PubMed]

123. Ostrand-Rosenberg, S.; Sinha, P.; Beury, D.W.; Clements, V.K. Cross-talk between myeloid-derived suppressor cells (MDSC), macrophages, and dendritic cells enhances tumor-induced immune suppression. Semin. Cancer Biol. 2012, 22, 275-281. [CrossRef] [PubMed]

124. Sinha, P.; Clements, V.K.; Fulton, A.M.; Ostrand-Rosenberg, S. Prostaglandin E2 promotes tumor progression by inducing myeloid-derived suppressor cells. Cancer Res. 2007, 67, 4507-4513. [CrossRef] [PubMed]

125. Poschke, I.; Mao, Y.; Adamson, L.; Salazar-Onfray, F.; Masucci, G.; Kiessling, R. Myeloid-derived suppressor cells impair the quality of dendritic cell vaccines. Cancer Immunol. Immunother. 2012, 61, 827-838. [CrossRef] [PubMed]

126. Hu, C.E.; Gan, J.; Zhang, R.D.; Cheng, Y.R.; Huang, G.J. Up-regulated myeloid-derived suppressor cell contributes to hepatocellular carcinoma development by impairing dendritic cell function. Scand. J. Gastroenterol. 2011, 46, 156-164. [CrossRef] [PubMed]

127. Langrish, C.L.; Chen, Y.; Blumenschein, W.M.; Mattson, J.; Basham, B.; Sedgwick, J.D.; McClanahan, T.; Kastelein, R.A.; Cua, D.J. IL-23 drives a pathogenic T cell population that induces autoimmune inflammation. J. Exp. Med. 2005, 201, 233-240. [CrossRef] [PubMed]

128. Xue, J.; Schmidt, S.V.; Sander, J.; Draffehn, A.; Krebs, W.; Quester, I.; De Nardo, D.; Gohel, T.D.; Emde, M.; Schmidleithner, L.; et al. Transcriptome-based network analysis reveals a spectrum model of human macrophage activation. Immunity 2014, 40, 274-288. [CrossRef] [PubMed]

129. Pullamsetti, S.S.; Savai, R. Macrophage Regulation during Vascular Remodeling: Implications for Pulmonary Hypertension Therapy. Am. J. Respir. Cell Mol. Biol. 2017, 56, 556-558. [CrossRef] [PubMed]

130. Tuder, R.M.; Groves, B.; Badesch, D.B.; Voelkel, N.F. Exuberant endothelial cell growth and elements of inflammation are present in plexiform lesions of pulmonary hypertension. Am. J. Pathol. 1994, 144, 275-285. [PubMed]

131. Vergadi, E.; Chang, M.S.; Lee, C.; Liang, O.D.; Liu, X.; Fernandez-Gonzalez, A.; Mitsialis, S.A.; Kourembanas, S. Early macrophage recruitment and alternative activation are critical for the later development of hypoxia-induced pulmonary hypertension. Circulation 2011, 123, 1986-1995. [CrossRef] [PubMed] 
132. El Kasmi, K.C.; Pugliese, S.C.; Riddle, S.R.; Poth, J.M.; Anderson, A.L.; Frid, M.G.; Li, M.; Pullamsetti, S.S.; Savai, R.; Nagel, M.A.; et al. Adventitial fibroblasts induce a distinct proinflammatory/profibrotic macrophage phenotype in pulmonary hypertension. J. Immunol. 2014, 193, 597-609. [CrossRef] [PubMed]

133. Ugel, S.; De Sanctis, F.; Mandruzzato, S.; Bronte, V. Tumor-induced myeloid deviation: When myeloid-derived suppressor cells meet tumor-associated macrophages. J. Clin. Investig. 2015, 125, 3365-3376. [CrossRef] [PubMed]

134. Savage, N.D.; de Boer, T.; Walburg, K.V.; Joosten, S.A.; van Meijgaarden, K.; Geluk, A.; Ottenhoff, T.H. Human anti-inflammatory macrophages induce Foxp3+ GITR+ CD25+ regulatory T. cells, which suppress via membrane-bound TGFbeta-1. J. Immunol. 2008, 181, 2220-2226. [CrossRef] [PubMed]

135. Thibodeau, J.; Bourgeois-Daigneault, M.C.; Huppe, G.; Tremblay, J.; Aumont, A.; Houde, M.; Bartee, E.; Brunet, A.; Gauvreau, M.E.; de Gassart, A.; et al. Interleukin-10-induced MARCH1 mediates intracellular sequestration of MHC class II in monocytes. Eur. J. Immunol. 2008, 38, 1225-1230. [CrossRef] [PubMed]

136. Austin, E.D.; Rock, M.T.; Mosse, C.A.; Vnencak-Jones, C.L.; Yoder, S.M.; Robbins, I.M.; Loyd, J.E.; Meyrick, B.O. T lymphocyte subset abnormalities in the blood and lung in pulmonary arterial hypertension. Respir. Med. 2010, 104, 454-462. [CrossRef] [PubMed]

137. Rabieyousefi, M.; Soroosh, P.; Satoh, K.; Date, F.; Ishii, N.; Yamashita, M.; Oka, M.; McMurtry, I.F.; Shimokawa, H.; Nose, M.; et al. Indispensable roles of OX40L-derived signal and epistatic genetic effect in immune-mediated pathogenesis of spontaneous pulmonary hypertension. BMC. Immunol. 2011, 12, 67-69. [CrossRef] [PubMed]

138. Huertas, A.; Tu, L.; Gambaryan, N.; Girerd, B.; Perros, F.; Montani, D.; Fabre, D.; Fadel, E.; Eddahibi, S.; Cohen-Kaminsky, S.; Guignabert, C. Leptin and regulatory T-lymphocytes in idiopathic pulmonary arterial hypertension. Eur. Respir. J. 2012, 40, 895-904. [CrossRef] [PubMed]

139. Ulrich, S.; Nicolls, M.R.; Taraseviciene, L.; Speich, R.; Voelkel, N. Increased regulatory and decreased CD8+ cytotoxic $\mathrm{T}$ cells in the blood of patients with idiopathic pulmonary arterial hypertension. Respiration 2008, 75, 272-780. [CrossRef] [PubMed]

140. Taraseviciene-Stewart, L.; Nicolls, M.R.; Kraskauskas, D.; Scerbavicius, R.; Burns, N.; Cool, C.; Wood, K.; Parr, J.E.; Boackle, S.A.; Voelkel, N.F. Absence of T cells confers increased pulmonary arterial hypertension and vascular remodeling. Am. J. Respir. Crit. Care Med. 2007, 175, 1280-1289. [CrossRef] [PubMed]

141. Daley, E.; Emson, C.; Guignabert, C.; de Waal Malefyt, R.; Louten, J.; Kurup, V.P.; Hogaboam, C.; Taraseviciene-Stewart, L.; Voelkel, N.F.; Rabinovitch, M.; et al. Pulmonary arterial remodeling induced by a Th2 immune response. J. Exp. Med. 2008, 205, 361-372. [CrossRef] [PubMed]

142. Cuttica, M.J.; Langenickel, T.; Noguchi, A.; Machado, R.F.; Gladwin, M.T.; Boehm, M. Perivascular T-cell infiltration leads to sustained pulmonary artery remodeling after endothelial cell damage. Am. J. Respir. Cell Mol. Biol. 2011, 45, 62-71. [CrossRef] [PubMed]

143. Tamosiuniene, R.; Tian, W.; Dhillon, G.; Wang, L.; Sung, Y.K.; Gera, L.; Patterson, A.J.; Agrawal, R.; Rabinovitch, M.; Ambler, K.; et al. Regulatory T cells limit vascular endothelial injury and prevent pulmonary hypertension. Circ. Res. 2011, 109, 867-879. [CrossRef] [PubMed]

144. Hautefort, A.; Girerd, B.; Montani, D.; Cohen-Kaminsky, S.; Price, L.; Lambrecht, B.N.; Humbert, M.; Perros, F. T-helper 17 cell polarization in pulmonary arterial hypertension. Chest 2015, 147, 1610-1620. [CrossRef] [PubMed]

145. Jasiewicz, M.; Moniuszko, M.; Pawlak, D.; Knapp, M.; Rusak, M.; Kazimierczyk, R.; Musial, W.J.; Dabrowska, M.; Kaminski, K.A. Activity of the kynurenine pathway and its interplay with immunity in patients with pulmonary arterial hypertension. Heart 2016, 102, 230-237. [CrossRef] [PubMed]

146. Harbaum, L.; Oqueka, T.; Glatzel, A.; Hennigs, J.K.; Luneburg, N.; Klose, H. Does circulating IL-17 identify a subset of patients with idiopathic pulmonary arterial hypertension? Chest 2015, 148, 131-132. [CrossRef] [PubMed]

147. Huertas, A.; Phan, C.; Bordenave, J.; Tu, L.; Thuillet, R.; Le Hiress, M.; Avouac, J.; Tamura, Y.; Allanore, Y.; Jovan, R.; et al. Regulatory T Cell Dysfunction in Idiopathic, Heritable and Connective Tissue-Associated Pulmonary Arterial Hypertension. Chest 2016, 149, 1482-1493. [CrossRef] [PubMed]

148. Hoechst, B.; Gamrekelashvili, J.; Manns, M.P.; Greten, T.F.; Korangy, F. Plasticity of human Th17 cells and iTregs is orchestrated by different subsets of myeloid cells. Blood 2011, 117, 6532-6541. [CrossRef] [PubMed] 
149. Ji, J.; Xu, J.; Zhao, S.; Liu, F.; Qi, J.; Song, Y.; Ren, J.; Wang, T.; Dou, H.; Hou, Y. Myeloid-derived suppressor cells contribute to systemic lupus erythaematosus by regulating differentiation of Th17 cells and Tregs. Clin. Sci. 2016, 130, 1453-1467. [CrossRef] [PubMed]

150. Wu, H.; Zhen, Y.; Ma, Z.; Li, H.; Yu, J.; Xu, Z.G.; Wang, X.Y.; Yi, H.; Yang, Y.G. Arginase-1-dependent promotion of TH17 differentiation and disease progression by MDSCs in systemic lupus erythematosus. Sci. Transl. Med. 2016, 8, 331-340. [CrossRef] [PubMed]

151. Lindau, D.; Gielen, P.; Kroesen, M.; Wesseling, P.; Adema, G.J. The immunosuppressive tumour network: Myeloid-derived suppressor cells, regulatory T cells and natural killer T. cells. Immunology 2013, 138, 105-115. [CrossRef] [PubMed]

152. Sangaletti, S.; Tripodo, C.; Santangelo, A.; Castioni, N.; Portararo, P.; Gulino, A.; Botti, L.; Parenza, M.; Cappetti, B.; Orlandi, R.; et al. Mesenchymal Transition of High-Grade Breast Carcinomas Depends on Extracellular Matrix Control of Myeloid Suppressor Cell Activity. Cell. Rep. 2016, 17, 233-248. [CrossRef] [PubMed]

153. Hammami, I.; Chen, J.; Murschel, F.; Bronte, V.; De Crescenzo, G.; Jolicoeur, M. Immunosuppressive activity enhances central carbon metabolism and bioenergetics in myeloid-derived suppressor cells in vitro models. BMC Cell Biol. 2012, 13, 18-24. [CrossRef] [PubMed]

154. Hossain, F.; Al-Khami, A.A.; Wyczechowska, D.; Hernandez, C.; Zheng, L.; Reiss, K.; Valle, L.D.; Trillo-Tinoco, J.; Maj, T.; Zou, W.; et al. Inhibition of Fatty Acid Oxidation Modulates Immunosuppressive Functions of Myeloid-Derived Suppressor Cells and Enhances Cancer Therapies. Cancer Immunol. Res. 2015, 3, 1236-1247. [CrossRef] [PubMed]

155. Liu, G.; Bi, Y.; Shen, B.; Yang, H.; Zhang, Y.; Wang, X.; Liu, H.; Lu, Y.; Liao, J.; Chen, X.; et al. SIRT1 limits the function and fate of myeloid-derived suppressor cells in tumors by orchestrating HIF-1alpha-dependent glycolysis. Cancer Res. 2014, 74, 727-737. [CrossRef] [PubMed]

156. Chen, X.; Lu, Y.; Zhang, Z.; Wang, J.; Yang, H.; Liu, G. Intercellular interplay between Sirt1 signalling and cell metabolism in immune cell biology. Immunology 2015, 145, 455-467. [CrossRef] [PubMed]

157. Min, Y.; Li, J.; Qu, P.; Lin, P.C. C/EBP-delta positively regulates MDSC expansion and endothelial VEGFR2 expression in tumor development. Oncotarget 2017, 8, 50582-50593. [CrossRef] [PubMed]

158. Bryant, A.J.; Carrick, R.P.; McConaha, M.E.; Jones, B.R.; Shay, S.D.; Moore, C.S.; Blackwell, T.R.; Gladson, S.; Penner, N.L.; Burman, A.; et al. Endothelial HIF signaling regulates pulmonary fibrosis-associated pulmonary hypertension. Am. J. Physiol. Lung Cell Mol. Physiol. 2016, 310, L249-L262. [CrossRef] [PubMed]

159. Kim, J.H.; Oh, S.H.; Kim, E.J.; Park, S.J.; Hong, S.P.; Cheon, J.H.; Kim, T.I.; Kim, W.H. The role of myofibroblasts in upregulation of S100A8 and S100A9 and the differentiation of myeloid cells in the colorectal cancer microenvironment. Biochem. Biophys. Res. Commun. 2012, 423, 60-66. [CrossRef] [PubMed]

160. Shi, Y.; Ou, L.; Han, S.; Li, M.; Pena, M.M.; Pena, E.A.; Liu, C.; Nagarkatti, M.; Fan, D.; Ai, W. Deficiency of Kruppel-like factor KLF4 in myeloid-derived suppressor cells inhibits tumor pulmonary metastasis in mice accompanied by decreased fibrocytes. Oncogenesis 2014, 3, 129-166. [CrossRef] [PubMed]

161. Sheikh, A.Q.; Misra, A.; Rosas, I.O.; Adams, R.H.; Greif, D.M. Smooth muscle cell progenitors are primed to muscularize in pulmonary hypertension. Sci. Transl. Med. 2015, 7, 308-359. [CrossRef] [PubMed]

162. Shatat, M.A.; Tian, H.; Zhang, R.; Tandon, G.; Hale, A.; Fritz, J.S.; Zhou, G.; Martinez-Gonzalez, J.; Rodriguez, C.; Champion, H.C.; et al. Endothelial Kruppel-like factor 4 modulates pulmonary arterial hypertension. Am. J. Respir. Cell Mol. Biol. 2014, 50, 647-653. [CrossRef] [PubMed]

163. Cottrill, K.A.; Chan, S.Y. Metabolic dysfunction in pulmonary hypertension: The expanding relevance of the Warburg effect. Eur. J. Clin. Investig. 2013, 43, 855-865. [CrossRef] [PubMed]

164. Tuder, R.M.; Davis, L.A.; Graham, B.B. Targeting energetic metabolism: A new frontier in the pathogenesis and treatment of pulmonary hypertension. Am. J. Respir. Crit. Care Med. 2012, 185, 260-266. [CrossRef] [PubMed]

165. Egnatchik, R.A.; Brittain, E.L.; Shah, A.T.; Fares, W.H.; Ford, H.J.; Monahan, K.; Kang, C.J.; Kocurek, E.G.; Zhu, S.; Luong, T.; et al. Dysfunctional BMPR2 signaling drives an abnormal endothelial requirement for glutamine in pulmonary arterial hypertension. Pulm. Circ. 2017, 7, 186-199. [CrossRef] [PubMed]

166. Fessel, J.P.; Hamid, R.; Wittmann, B.M.; Robinson, L.J.; Blackwell, T.; Tada, Y.; Tanabe, N.; Tatsumi, K.; Hemnes, A.R.; West, J.D. Metabolomic analysis of bone morphogenetic protein receptor type 2 mutations in human pulmonary endothelium reveals widespread metabolic reprogramming. Pulm. Circ 2012, 2, 201-213. [CrossRef] [PubMed] 
167. Rafikov, R.; Sun, X.; Rafikova, O.; Meadows, M.L.; Desai, A.A.; Khalpey, Z.; Yuan, J.X.; Fineman, J.R.; Black, S.M. Complex I dysfunction underlies the glycolytic switch in pulmonary hypertensive smooth muscle cells. Redox. Biol. 2015, 6, 278-286. [CrossRef] [PubMed]

168. Paffett, M.L.; Lucas, S.N.; Campen, M.J. Resveratrol reverses monocrotaline-induced pulmonary vascular and cardiac dysfunction: A potential role for atrogin-1 in smooth muscle. Vascul. Pharmacol. 2012, 56, 64-73. [CrossRef] [PubMed]

169. Yu, L.; Tu, Y.; Jia, X.; Fang, K.; Liu, L.; Wan, L.; Xiang, C.; Wang, Y.; Sun, X.; Liu, T.; et al. Resveratrol Protects Against Pulmonary Arterial Hypertension in Rats via Activation of Silent Information Regulator 1. Cell Physiol. Biochem. 2017, 42, 55-67. [CrossRef] [PubMed]

170. Meyer, C.; Sevko, A.; Ramacher, M.; Bazhin, A.V.; Falk, C.S.; Osen, W.; Borrello, I.; Kato, M.; Schadendorf, D.; Baniyash, M.; et al. Chronic inflammation promotes myeloid-derived suppressor cell activation blocking antitumor immunity in transgenic mouse melanoma model. Proc. Natl. Acad. Sci. USA 2011, 108, 17111-17116. [CrossRef] [PubMed]

171. Serafini, P.; Meckel, K.; Kelso, M.; Noonan, K.; Califano, J.; Koch, W.; Dolcetti, L.; Bronte, V.; Borrello, I. Phosphodiesterase-5 inhibition augments endogenous antitumor immunity by reducing myeloid-derived suppressor cell function. J. Exp. Med. 2006, 203, 2691-2702. [CrossRef] [PubMed]

172. Tai, L.H.; Alkayyal, A.A.; Leslie, A.L.; Sahi, S.; Bennett, S.; Tanese de Souza, C.; Baxter, K.; Angka, L.; Xu, R.; Kennedy, M.A.; et al. Phosphodiesterase- 5 inhibition reduces postoperative metastatic disease by targeting surgery-induced myeloid derived suppressor cell-dependent inhibition of Natural Killer cell cytotoxicity. Oncoimmunology 2018, 7, e1431082. [CrossRef] [PubMed]

173. Califano, J.A.; Khan, Z.; Noonan, K.A.; Rudraraju, L.; Zhang, Z.; Wang, H.; Goodman, S.; Gourin, C.G.; Ha, P.K.; Fakhry, C.; et al. Tadalafil augments tumor specific immunity in patients with head and neck squamous cell carcinoma. Clin. Cancer Res. 2015, 21, 30-38. [CrossRef] [PubMed]

174. Noonan, K.A.; Ghosh, N.; Rudraraju, L.; Bui, M.; Borrello, I. Targeting immune suppression with PDE5 inhibition in end-stage multiple myeloma. Cancer Immunol. Res. 2014, 2, 725-731. [CrossRef] [PubMed]

175. Weber, R.; Fleming, V.; Hu, X.; Nagibin, V.; Groth, C.; Altevogt, P.; Utikal, J.; Umansky, V. Myeloid-Derived Suppressor Cells Hinder the Anti-Cancer Activity of Immune Checkpoint Inhibitors. Front. Immunol. 2018, 9 , 13-15. [CrossRef] [PubMed]

176. Iclozan, C.; Antonia, S.; Chiappori, A.; Chen, D.T.; Gabrilovich, D. Therapeutic regulation of myeloid-derived suppressor cells and immune response to cancer vaccine in patients with extensive stage small cell lung cancer. Cancer Immunol. Immunother. 2013, 62, 909-918. [CrossRef] [PubMed]

177. Mirza, N.; Fishman, M.; Fricke, I.; Dunn, M.; Neuger, A.M.; Frost, T.J.; Lush, R.M.; Antonia, S.; Gabrilovich, D.I. All-trans-retinoic acid improves differentiation of myeloid cells and immune response in cancer patients. Cancer Res. 2006, 66, 9299-9307. [CrossRef] [PubMed]

178. Qin, Y.; Zhou, A.; Ben, X.; Shen, J.; Liang, Y.; Li, F. All-trans retinoic acid in pulmonary vascular structural remodeling in rats with pulmonary hypertension induced by monocrotaline. Chin. Med. J. 2001, 114, 462-465. [PubMed]

179. Xin, Y.; Lv, J.Q.; Wang, Y.Z.; Zhang, J.; Zhang, X. Effect of all-trans retinoic acids (ATRA) on the expression of alpha-smooth muscle actin (alpha-SMA) in the lung tissues of rats with pulmonary arterial hypertension (PAH). Genet. Mol. Res. 2015, 14, 14308-14313. [CrossRef] [PubMed]

180. Zhang, E.; Jiang, B.; Yokochi, A.; Maruyama, J.; Mitani, Y.; Ma, N.; Maruyama, K. Effect of all-trans-retinoic acid on the development of chronic hypoxia-induced pulmonary hypertension. Circ. J. 2010, 74, 1696-1703. [CrossRef] [PubMed]

181. Zhang, Q.; Hossain, D.M.; Duttagupta, P.; Moreira, D.; Zhao, X.; Won, H.; Buettner, R.; Nechaev, S.; Majka, M.; Zhang, B.; et al. Serum-resistant CpG-STAT3 decoy for targeting survival and immune checkpoint signaling in acute myeloid leukemia. Blood 2016, 127, 1687-1700. [CrossRef] [PubMed]

182. Hong, D.; Kurzrock, R.; Kim, Y.; Woessner, R.; Younes, A.; Nemunaitis, J.; Fowler, N.; Zhou, T.; Schmidt, J.; Jo, M.; et al. AZD9150, a next-generation antisense oligonucleotide inhibitor of STAT3 with early evidence of clinical activity in lymphoma and lung cancer. Sci. Transl. Med. 2015, 7, 314-385. [CrossRef] [PubMed]

183. Tamosiuniene, R.; Manouvakhova, O.; Mesange, P.; Saito, T.; Qian, J.; Sanyal, M.; Lin, Y.C.; Nguyen, L.P.; Luria, A.; Tu, A.B.; et al. Dominant Role for Regulatory T Cells in Protecting Females Against Pulmonary Hypertension. Circ. Res. 2018, 122, 1689-1702. [CrossRef] [PubMed] 
184. Kim, S.H.; Li, M.; Trousil, S.; Zhang, Y.; Pasca di Magliano, M.; Swanson, K.D.; Zheng, B. Phenformin Inhibits Myeloid-Derived Suppressor Cells and Enhances the Anti-Tumor Activity of PD-1 Blockade in Melanoma. J. Invest. Dermatol. 2017, 137, 1740-1748. [CrossRef] [PubMed]

185. Fahlen, M.; Bergman, H.; Helder, G.; Ryden, L.; Wallentin, I.; Zettergren, L. Phenformin and pulmonary hypertension. Br. Heart J. 1973, 35, 824-828. [CrossRef] [PubMed]

186. Agard, C.; Rolli-Derkinderen, M.; Dumas-de-La-Roque, E.; Rio, M.; Sagan, C.; Savineau, J.P.; Loirand, G.; Pacaud, P. Protective role of the antidiabetic drug metformin against chronic experimental pulmonary hypertension. Br. J. Pharmacol. 2009, 158, 1285-1294. [CrossRef] [PubMed]

187. Lai, Y.C.; Tabima, D.M.; Dube, J.J.; Hughan, K.S.; Vanderpool, R.R.; Goncharov, D.A.; St Croix, C.M.; Garcia-Ocana, A.; Goncharova, E.A.; Tofovic, S.P.; et al. SIRT3-AMP-Activated Protein Kinase Activation by Nitrite and Metformin Improves Hyperglycemia and Normalizes Pulmonary Hypertension Associated with Heart Failure With Preserved Ejection Fraction. Circulation 2016, 133, 717-731. [PubMed]

188. Qin, G.; Lian, J.; Huang, L.; Zhao, Q.; Liu, S.; Zhang, Z.; Chen, X.; Yue, D.; Li, L.; Li, F.; et al. Metformin blocks myeloid-derived suppressor cell accumulation through AMPK-DACH1-CXCL1 axis. Oncoimmunology 2018, 7, e1442167. [CrossRef] [PubMed]

189. Di Mitri, D.; Toso, A.; Chen, J.J.; Sarti, M.; Pinton, S.; Jost, T.R.; D'Antuono, R.; Montani, E.; Garcia-Escudero, R.; Guccini, I.; et al. Tumour-infiltrating Gr-1+ myeloid cells antagonize senescence in cancer. Nature 2014, 515, 134-137. [CrossRef] [PubMed]

190. Blattner, C.; Fleming, V.; Weber, R.; Himmelhan, B.; Altevogt, P.; Gebhardt, C.; Schulze, T.J.; Razon, H.; Hawila, E.; Wildbaum, G.; et al. CCR5(+) Myeloid-Derived Suppressor Cells Are Enriched and Activated in Melanoma Lesions. Cancer Res. 2018, 78, 157-167. [CrossRef] [PubMed]

191. Nicolls, M.R.; Voelkel, N.F. The Roles of Immunity in the Prevention and Evolution of Pulmonary Arterial Hypertension. Am. J. Respir. Crit. Care. Med. 2017, 195, 1292-1299. [CrossRef] [PubMed]

192. Fleming, V.; Hu, X.; Weber, R.; Nagibin, V.; Groth, C.; Altevogt, P.; Utikal, J.; Umansky, V. Targeting Myeloid-Derived Suppressor Cells to Bypass Tumor-Induced Immunosuppression. Front. Immunol. 2018, 9 , 398-417. [CrossRef] [PubMed]

(C) 2018 by the authors. Licensee MDPI, Basel, Switzerland. This article is an open access article distributed under the terms and conditions of the Creative Commons Attribution (CC BY) license (http:/ / creativecommons.org/licenses/by/4.0/). 